\title{
Alkylpotassium-Catalyzed Benzylic C-H Alkylation of Alkylarenes with Alkenes
}

\author{
lo Sato \\ Yasuhiro Yamashita* \\ Shū Kobayashi* ${ }^{\mathbb{C}}$ \\ Department of Chemistry, School of Science, The University of \\ Tokyo, 7-3-1 Hongo, Bunkyo-ku, Tokyo, 113-0033, Japan \\ shu_kobayashi@chem.s.u-tokyo.ac.jp \\ yyamashita@chem.s.u-tokyo.ac.jp
}

Published as part of the 50 Years SYNTHESIS - Golden Anniversary Issue
Received: 17.10 .2018

Accepted: 18.10 .2018

Published online: 26.11 .2018

DOI: 10.1055/s-0037-1610378; Art ID: ss-2018-z0702-fa

License terms: (c)

Abstract Catalytic benzylic $\mathrm{C}-\mathrm{H}$ alkylation reactions of alkylarenes with alkenes such as $\beta$-substituted styrenes and vinylsilanes have been achieved by utilizing alkylpotassium as a catalyst. Various substituted toluene derivatives can be alkylated under mild reaction conditions to afford the desired functionalized hydrocarbons in moderate to high yields.

Key words strong base, alkylarene, alkylation, alkylpotassium, alkene

Catalytic benzylic $\mathrm{C}-\mathrm{H}$ functionalization of alkylarenes, such as toluene and xylene, toward $\mathrm{C}-\mathrm{C}$ bond formation is among the most simple and efficient methods for the introduction of a benzyl moiety into complex organic molecules, such as pharmaceuticals and natural products, because alkylarenes are abundant, inexpensive, and easy-to-handle starting materials. ${ }^{1}$ In the past several decades, chemists have developed these types of reactions, and one general approach is benzylic $\mathrm{C}-\mathrm{H}$ activation of alkylarenes to produce benzylic radical intermediates (Scheme 1a, top panel). ${ }^{1,2}$ Although many types of transition-metal-catalyzed reactions have been achieved, there are several disadvantages, such as harsh reaction conditions and the use of excess amounts of oxidants (e.g., tert-butyl hydroperoxide). Alternative reactions (carbene insertion, ${ }^{3}$ photocatalysis, ${ }^{4}$ Ru-catalyzed condensation ${ }^{5}$ ) were also reported, but precious and toxic transition metals were required as catalysts. Therefore, much milder, atom-economical, and efficient reactions are in high demand. ${ }^{6}$ Brønsted base catalyzed $\mathrm{C}-\mathrm{C}$ bond formation is one of the most ideal methods for the construction of carbon frameworks because of the high efficiency and atom-economy of the approach. ${ }^{7}$ Although there are thousands of Brønsted base-catalyzed $\mathrm{C}-\mathrm{C}$ bond

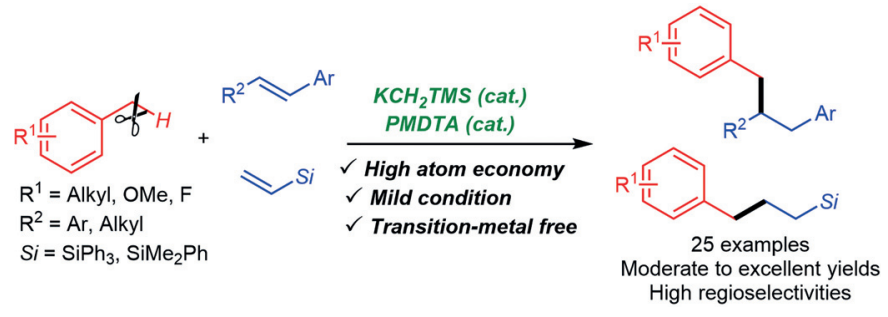

forming reactions reported, there is a severe limitation with respect to the acidity of the hydrogen of pro-nucleophiles $\left(\mathrm{p} K_{\mathrm{a}}<25\right)$. As for toluene ( $\mathrm{p} K_{\mathrm{a}}$ value of benzylic hydrogen ca. 43), ${ }^{8}$ stoichiometric amounts of strong base species such as Schlosser's base ${ }^{9}$ are required for the functionalization of toluene via benzylic anionic species (Scheme 1a, bottom panel).

(a) Conventional approach:

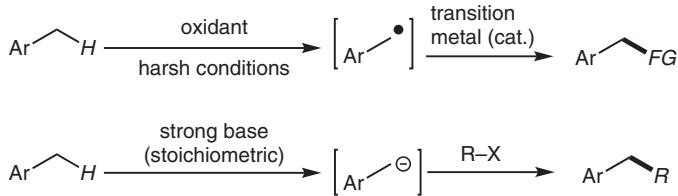

(b) Previous work:

Strong base-catalyzed addition reactions of alkylarenes with imines

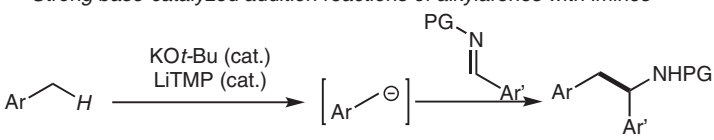

(c) This work

Strong base-catalyzed alkylation of alkylarens with olefins

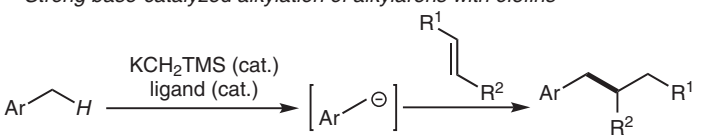

Scheme 1 Benzylic C-H functionalization of alkylarenes

Recently, our group has made an effort to break this limitation by focusing on the basicity of reaction intermediates. ${ }^{10,11}$ By using this strategy, we have reported the strong Brønsted base-catalyzed addition reactions of esters, ${ }^{11 a, b}$ amides, ${ }^{11 \mathrm{c}}$ nitriles, ${ }^{11 \mathrm{~d}}$ alkylaza-arenes, ${ }^{11 \mathrm{e}}$ and so on. Quite recently, we have developed potassium tert-butoxide/lithium tetramethylpiperidide (KOt-Bu/LiTMP) mixed base-catalyzed addition reactions of alkylarenes with $\mathrm{N}$-alkylimines (Scheme 1b). ${ }^{12}$ In this reaction, a highly basic reaction intermediate ( $N$-dialkylamide) functions as a base to deprotonate 
a benzylic hydrogen of the alkylarene (or a conjugate acid of $\mathrm{KOt}$-Bu/LiTMP mixed base) to promote a catalytic turnover. We next turned our attention to alkenes, especially styrene derivatives as electrophiles, ${ }^{13}$ by which formal alkylation of the benzylic positions of alkylarenes might be achieved.

As pioneering work, Pines et al. reported sodium or potassium metal-catalyzed addition reactions of alkylarenes with styrene derivatives. ${ }^{14}$ These reactions required elevated temperature, and poor-to-moderate yields of the desired mono-adducts were obtained due to production of polymeric by-products. Screttes et al. reported $\mathrm{Li} / \mathrm{K} / \mathrm{Mg}$ mixed base-catalyzed alkylation of alkylarenes with ethylene under high-pressure conditions. ${ }^{15}$ However, substrates were limited to methylated benzenes such as toluene derivatives and xylenes. Herein, we describe strong Brønsted base catalyzed addition reactions of alkylarenes with alkenes under mild reaction conditions to afford the desired functionalized hydrocarbons (Scheme 1c). ${ }^{16}$
Initially, in the presence of $30 \mathrm{~mol} \% \mathrm{KOt}-\mathrm{Bu} / \mathrm{LiTMP}$, the addition reaction of toluene (1a) with styrene $\left(\mathbf{2}^{\prime}\right)$ was conducted (Table 1 , entry 1 ). It was found that only a trace amount of the desired product was obtained, and oligomers derived from styrenes were observed. To suppress the oligomerization, trans-stilbene (2a) was used as an electrophile, and then the desired product (3aa) was obtained in $47 \%$ yield, while the by-product 3' was obtained in $12 \%$ yield (entry 2). To increase the reactivity and the selectivity between the product and the by-product, further optimization was conducted. First, $N, N, N^{\prime}, N^{\prime}$-tetramethylethylenediamine (TMEDA) was added to the reaction as a ligand to obtain the desired product in $86 \%$ yield (entry 3 ). ${ }^{17}$ The catalyst loading could be reduced to $10 \mathrm{~mol} \%$ without any reduction in the yield (entry 4). $N, N, N^{\prime}, N^{\prime \prime}, N^{\prime \prime}$-Pentamethyldiethylenetriamine (PMDTA) as a ligand gave a slightly increased yield compared with TMEDA (entry 5). Next, several solvents were tested for the reaction; the reaction in cyclopentyl methyl ether (CPME) showed the best selectivity

\begin{tabular}{|c|c|c|c|}
\hline iogr & & & \\
\hline$=\int_{0}^{\infty}$ & $\begin{array}{l}\text { Io Sato is a graduate student in } \\
\text { the Department of Chemistry, } \\
\text { Graduate School of Science, the } \\
\text { University of Tokyo, Japan. He } \\
\text { obtained his B.Sc. and M.Sc. de- }\end{array}$ & $\begin{array}{l}\text { grees under the supervision of } \\
\text { Prof. Shū Kobayashi in } 2014 \\
\text { and } 2016 \text {, respectively. Now he } \\
\text { is working as a Ph.D. course stu- } \\
\text { dent in the same group. His re- }\end{array}$ & $\begin{array}{l}\text { search focuses on C-C bond } \\
\text { forming reactions using inert } \\
\text { compounds catalyzed by strong } \\
\text { Brønsted bases. }\end{array}$ \\
\hline
\end{tabular}
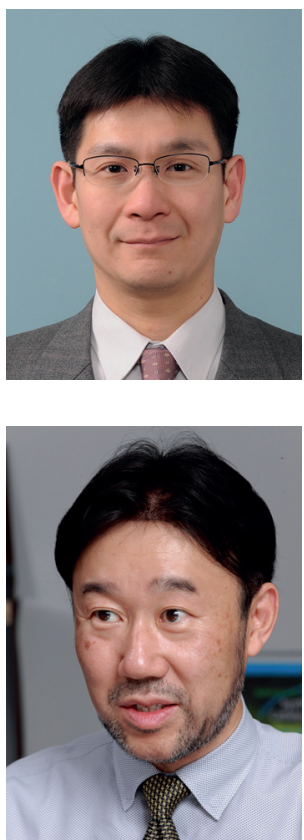

Yasuhiro Yamashita studied sor, Professor Shū Kobayashi). chemistry at the Graduate School of Pharmaceutical Sciences, The University of Tokyo, and received his Master degree in 1998 (supervisor, the late Professor Kenji Koga) and his Ph.D. degree in 2001 (supervi-

Shū Kobayashi studied at the University of Tokyo, receiving his Ph.D. degree in 1988 working under the direction of Professor Teruaki Mukaiyama. Following an initial period as assistant professor, he was pro-
He started his academic career as an assistant professor in 2001 in the Graduate School of Pharmaceutical Sciences, the University of Tokyo. He then joined Professor John F. Hartwig's group at Yale University as a

moted to lecturer then associate professor at the Sci1998, he moved to the Graduate School of Pharmaceutical Sciences, The University of Tokyo, as full professor. In April ence University of Tokyo. In postdoctoral fellow (20052006). He returned to the University of Tokyo and was promoted to an associate professor in the Department of Chemistry, School of Science (2007).

2007, he was appointed to his current position as professor of organic chemistry in the Department of Chemistry, within the Faculty of Science of The University of Tokyo. 
Table 1 Optimization of the Reaction Conditions ${ }^{\mathrm{a}}$

\begin{tabular}{|c|c|c|c|c|c|c|c|}
\hline \multirow[b]{2}{*}{ Entry } & \multirow[b]{2}{*}{$R$} & & & $\begin{array}{l}\left(\begin{array}{l}x \mathrm{~mol} \%) \\
\mathrm{x} \mathrm{mol} \%) \\
(\mathrm{x} \mathrm{mol} \%)\end{array}\right. \\
\underset{\mathrm{M}, \text { r.t., } 24 \mathrm{~h}}{\longrightarrow}\end{array}$ & \multirow{2}{*}{$\begin{array}{c}\text { 3aa } \\
\text { Solvent }\end{array}$} & 3' & \multirow[b]{2}{*}{ Yield $(\%)^{\mathrm{b}}$ of 3} \\
\hline & & $A$ (equiv) & $x(\mathrm{~mol} \%)$ & Additive & & Yield (\%) ${ }^{\mathrm{b}}$ of $3 \mathrm{aa}$ & \\
\hline $1^{\mathrm{c}}$ & $\mathrm{H}$ & $\sim 47$ & 30 & - & toluene & trace & - \\
\hline $2^{\mathrm{d}}$ & $\mathrm{Ph}$ & $\sim 47$ & 30 & - & toluene & 47 & 12 \\
\hline $3^{d}$ & $\mathrm{Ph}$ & $\sim 47$ & 30 & TMEDA & toluene & 86 & 4 \\
\hline 4 & $\mathrm{Ph}$ & $\sim 47$ & 10 & TMEDA & toluene & 86 & 4 \\
\hline 5 & $\mathrm{Ph}$ & $\sim 47$ & 10 & PMDTA & toluene & 88 & 2 \\
\hline 6 & $\mathrm{Ph}$ & 4.0 & 10 & PMDTA & heptane & 70 & 10 \\
\hline 7 & $\mathrm{Ph}$ & 4.0 & 10 & PMDTA & $\mathrm{Et}_{2} \mathrm{O}$ & 44 & 6 \\
\hline 8 & $\mathrm{Ph}$ & 4.0 & 10 & PMDTA & CPME & 50 & 6 \\
\hline $9^{e}$ & $\mathrm{Ph}$ & 4.0 & 10 & PMDTA & CPME & 98 & 2 \\
\hline
\end{tabular}

a The reaction of $1 \mathbf{a}$ with $\mathbf{2}(0.3 \mathrm{mmol})$ was conducted in the presence of KOt-Bu, LiTMP, and an additive at r.t. for $24 \mathrm{~h}$, unless otherwise noted.

${ }^{\mathrm{b}} \mathrm{NMR}$ yield.

c Time: $18 \mathrm{~h}$.

d Time: $13 \mathrm{~h}$.

e Conditions: $20 \mathrm{~mol} \%$ of PMDTA, $0.8 \mathrm{M}, 0{ }^{\circ} \mathrm{C}$.

toward the product (entry 8). Finally, a higher ligand loading (20 mol\%), higher concentration, and lower reaction temperature gave the desired product in $98 \%$ yield (entry 9 ). To check the effect of substituents on the aromatic ring of the nucleophile, the addition reaction of $p$-methoxy-substituted toluene, $p$-methylanisole (1) $\mathbf{1})$, as a nucleophile was conducted under the optimal reaction conditions. ${ }^{18}$ However, although the electrophile was completely consumed, the desired product $\mathbf{3 b a}$ was obtained in only $32 \%$ yield and the reaction system became complex (Table 2 , entry 1 ). Analysis of the by-products revealed that the aryl-exchanged products 3ba' and 3aa were produced.

For the mechanism of by-product formation, it was assumed that the substituted stilbene and the benzyl anion of toluene were produced through a deprotonation/elimination pathway of the product, and then the substituted stilbene was attacked by a second nucleophilic benzyl anion of $\mathbf{1 b}$ to form by-product $\mathbf{3} \mathbf{b a}$ ', and the benzyl anion of toluene attacked another stilbene to form by-product 3aa (Scheme 2). Similar phenomena were also observed in the reactions of other nucleophiles. To suppress this by-product formation, screening of strong base catalysts was conducted, and it was found that, in the presence of catalytic amounts of (trimethylsilyl)methylpotassium $\left(\mathrm{KCH}_{2} \mathrm{TMS}\right)^{19}$ and PMDTA as a strong base catalyst and a ligand, respectively, by-product formation was suppressed, and the desired product was obtained in $79 \%$ yield (Table 2, entry 2). Potassium amide generated in situ as a catalyst gave almost the same result (entry 3). On the other hand, in the presence of lithium cations, the yield of the desired product decreased, and by-
Table 2 Screening of Base Catalysts
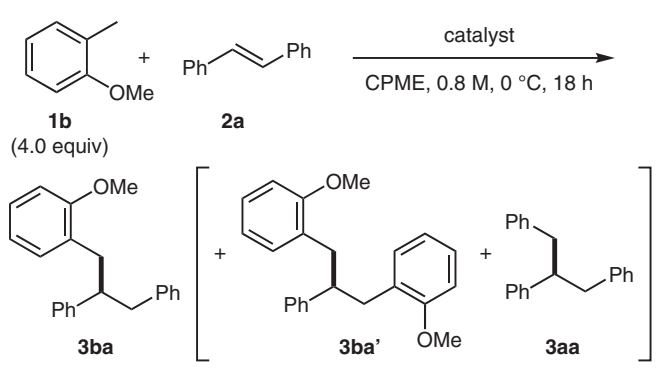

\begin{tabular}{|c|c|c|}
\hline Entry & Catalyst & Yield (\%) ${ }^{\mathrm{b}}$ of $\mathbf{3 b a}$ \\
\hline 1 & $\begin{array}{l}\text { KOt-Bu (10 mol\%) } \\
\text { LiTMP (10 mol\%) } \\
\text { PMDTA (20 mol\%) }\end{array}$ & 32 \\
\hline 2 & $\begin{array}{l}\mathrm{KCH}_{2} \text { TMS ( } 10 \text { mol\%) } \\
\text { PMDTA (10 mol\%) }\end{array}$ & 79 \\
\hline 3 & $\begin{array}{l}\mathrm{KCH}_{2} \text { TMS (10 mol\%) } \\
\text { H-TMP (10 mol\%) } \\
\text { PMDTA ( } 10 \mathrm{~mol} \%)\end{array}$ & 81 \\
\hline 4 & $\begin{array}{l}\mathrm{KCH}_{2} \text { TMS (10 mol\%) } \\
\text { LiTMP ( } 10 \text { mol\%) } \\
\text { PMDTA ( } 20 \text { mol\%) }\end{array}$ & 26 \\
\hline 5 & $\begin{array}{l}\mathrm{KCH}_{2} \text { TMS (10 mol\%) } \\
\text { LiOt-Bu (10 mol\%) } \\
\text { PMDTA ( } 20 \text { mol\%) }\end{array}$ & 25 \\
\hline 6 & $\begin{array}{l}\mathrm{KCH}_{2} \text { TMS ( } 2 \text { mol\%) } \\
\text { PMDTA ( } 2 \text { mol\%) }\end{array}$ & $86(78)^{c}$ \\
\hline
\end{tabular}

a The reaction of $\mathbf{1 b}$ (4.0 equiv) with $\mathbf{2}(0.3 \mathrm{mmol})$ in CPME $(0.8 \mathrm{M})$ was conducted in the presence of a catalyst at $0{ }^{\circ} \mathrm{C}$ for $18 \mathrm{~h}$, unless otherwise noted.

${ }^{\mathrm{b}}$ NMR yield.

' Isolated yield. 
product formation was accelerated (entries 4 and 5). These results implied that the presence of lithium cations facilitated by-product formation, probably because altering the aggregation states of the reaction intermediates enhanced their basicity and facilitated a deprotonation/elimination pathway leading to by-product formation. ${ }^{20}$ Finally, the catalyst loading could be reduced to $2 \mathrm{~mol} \% \mathrm{KCH}_{2} \mathrm{TMS}$ and PMDTA to afford the desired product in $78 \%$ isolated yield (entry 6).

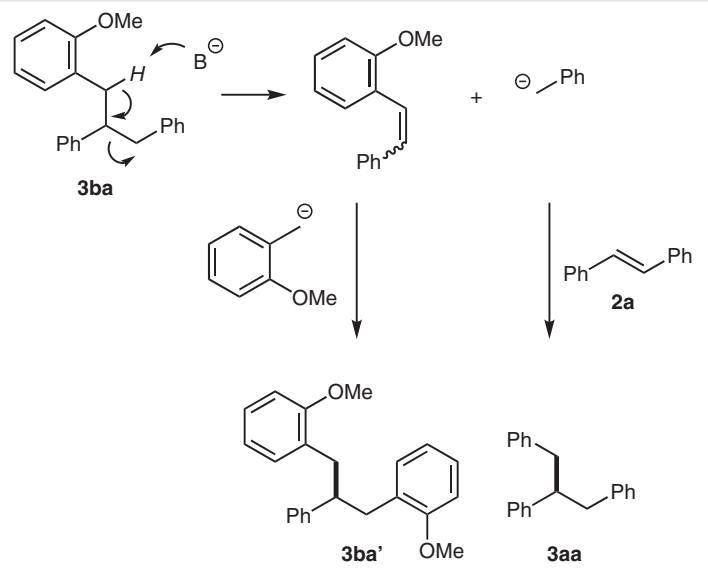

Scheme 2 Assumed pathway for by-product formation

The catalytic addition reactions of various substituted alkylarenes with stilbenes were then investigated (Scheme 3 ). Under the neat Condition A, the product 3aa was obtained in high yield with only $1 \mathrm{~mol} \%$ catalyst. The reactions of methoxy- or fluoro-substituted toluene derivatives were conducted in CPME as solvent (Condition B). Both 0 - and $m$ methoxy-substituted toluenes gave the desired products 3ba and 3ca, respectively, in high yields. Unfortunately, pmethoxytoluene showed lower reactivity and selectivity toward the desired product, and the desired product was obtained in up to ca. $30 \%$ yield under several modified reaction conditions, probably because of the low acidity of the benzylic hydrogen. Disubstituted toluene was also subjected to the reaction conditions. The reaction of 3,5-dimethylanisole was conducted to afford the product 3da in moderate yield. The low nucleophilicity and low durability of fluoro-substituted toluene under strongly basic reaction conditions meant that higher catalyst loading and a slightly lower reaction temperature were required for their reactions to afford the desired products 3ea and 3fa in moderate-to-good yields. For the reactions of xylenes, neat conditions (Condition A) were adopted. The reaction of $o$ - and $m$ xylene proceeded smoothly to afford the desired compounds 3ga and 3ha in high yields with 1 or $2 \mathrm{~mol} \%$ catalyst.

$p$-Xylene showed lower reactivity; in this case, elevated temperature and prolonged reaction time gave the desired compound 3ia in moderate yield. The reaction with $p$-isopropyltoluene was sluggish, and $5 \mathrm{~mol} \%$ catalyst was required to obtain the desired compound $\mathbf{3 j a}$ in moderate yield. The reaction of ethylbenzene in the presence of 10 mol\% catalyst afforded almost quantitative amounts of the product 3ka with moderate diastereoselectivity.

Reactions of toluene with di-substituted symmetrical stilbene derivatives 2 were then conducted (Scheme 4). 4tert-Butyl- and 3-methoxy-substituted stilbenes were good substrates and afforded the products 3ab and 3ac in high

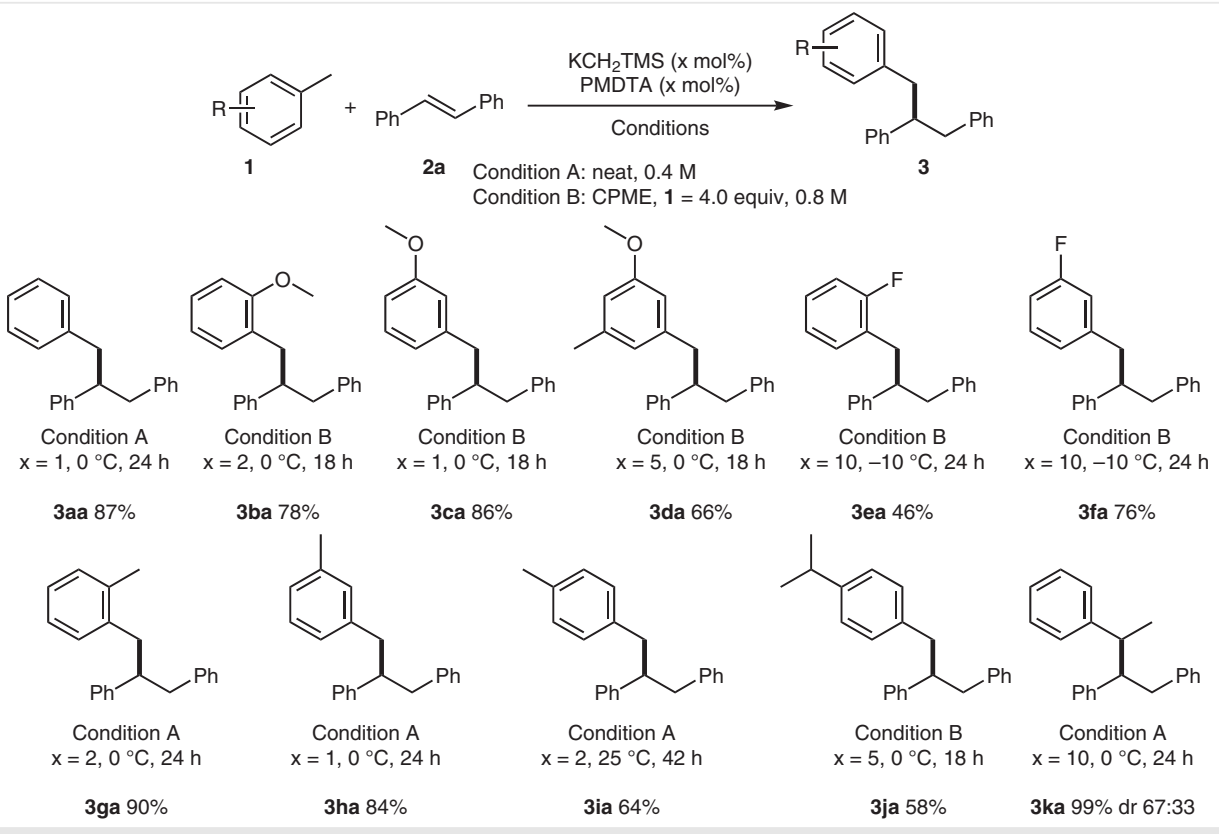

Scheme 3 Substrate scope of the reaction with respect to nucleophiles 
244

Synthesis

I. Soto et al.

THEME

I. Soto et al.

OPEN
ACCESS

Feature

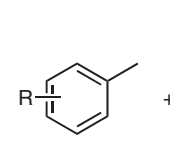

1

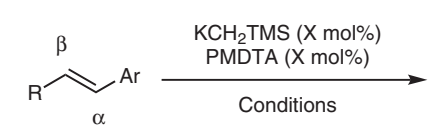

2 Condition A: neat, $0.4 \mathrm{M}$ Condition B: CPME, 1 = 4.0 equiv, $0.8 \mathrm{M}$

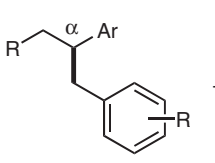

$\alpha$-adduct<smiles>[R]C(CBr)CC1=CC=[I+]=C=C1</smiles>

3

$\beta$-adduct
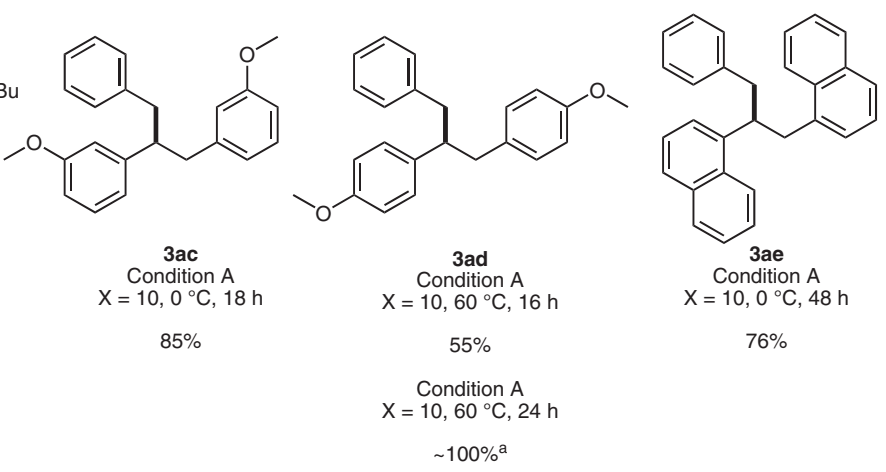<smiles>CCC(C)(C)c1ccc(CC(Cc2ccccc2)c2ccc(Br)cc2)cc1</smiles>
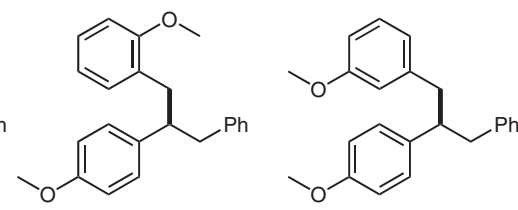<smiles>COc1ccccc1CC(Cc1ccccc1)c1ccccc1</smiles>
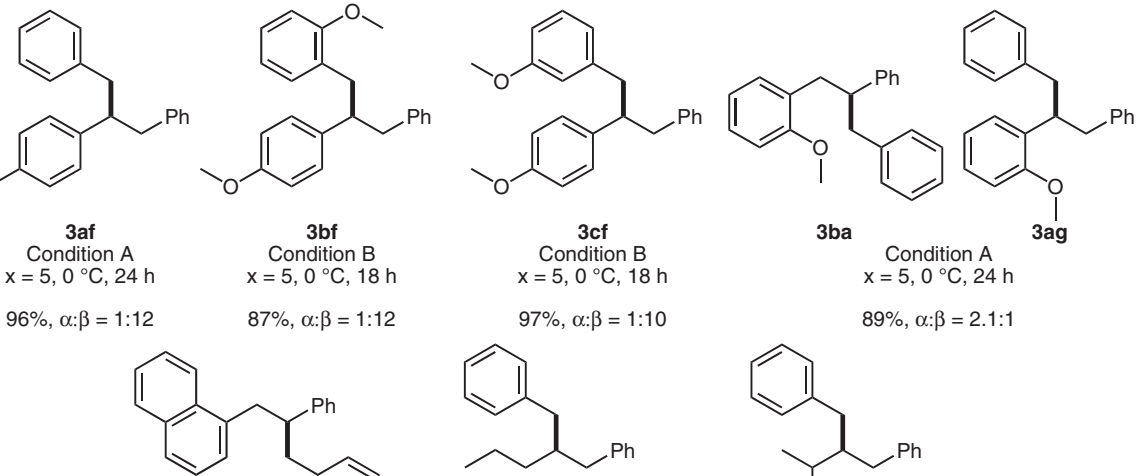

Sba

$76 \%$<smiles>COc1ccc(C(Cc2ccccc2)Cc2ccccc2)cc1</smiles>
Condition $\mathrm{A}$
$\mathrm{x}=5,0^{\circ} \mathrm{C}, 24 \mathrm{~h}$ $96 \%, \alpha: \beta=1: 12 \quad 87 \%, \alpha: \beta=1: 12$
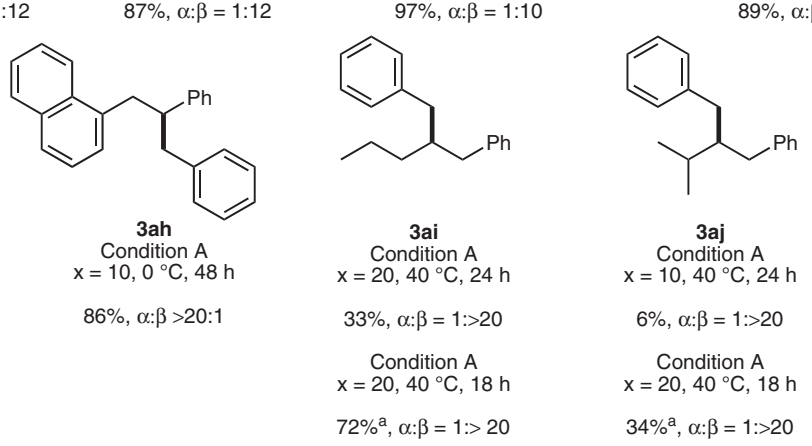

3aj $\mathrm{x}=10,40^{\circ} \mathrm{C}, 24 \mathrm{~h}$

$6 \%, \alpha: \beta=1:>20$

Condition $\mathrm{A}$

$\mathrm{x}=20,40^{\circ} \mathrm{C}, 18 \mathrm{~h}$

$34 \%{ }^{\mathrm{a}}, \alpha: \beta=1:>20$

Scheme 4 Substrate scope of the reaction with respect to electrophiles. ${ }^{\text {a }} \mathrm{KOt}-\mathrm{Bu} / \mathrm{LiTMP}$ was used as catalyst instead of $\mathrm{KCH}_{2} \mathrm{TMS}$

yields. For the reaction of 4-methoxy-substituted stilbene, a higher reaction temperature was required because of the low electrophilicity of the substrate; the use of $\mathrm{KOt}$-Bu/LiTMP as catalyst also gave a higher yield compared with the reactions with $\mathrm{KCH}_{2}$ TMS, affording the product Bad in excellent yield. The latter result probably stems from the higher stability of the catalytic species derived from NOt$\mathrm{Bu} / \mathrm{LiTMP}$ at high temperature. 1-Naphthyl-substituted alkene exhibited lower reactivity; nevertheless, conducting the reaction for longer time gave compound nae in good yield. The addition reactions of alkylarenes with unsymmetrical stilbenes were also examined. For the unsymmetrical stilbenes, two regioisomers, $\alpha$ - and $\beta$-adducts, are possible.
The reactions of toluene with 4-methoxy-substituted stilbene gave the $\beta$-adduct af in high yield and with high regioselectivity. The selectivity could be attributed to the lower stability of the $\alpha$-adduct reaction intermediate compared with that of the $\beta$-adduct because of the electron-dohating 4-methoxy group. Both $o$ - and $m$-methoxytoluene derivatives were good substrates, affording the desired bydrocarbons $\mathbf{3 b f}$ and cf, respectively, in high yields and with high selectivities. On the other hand, the use of 2-methoxy-substituted stilbene resulted in lower regioselectivity (ratio of $\alpha$-adduct ba to $\beta$-adduct Bag, 2.2:1), probably because of steric hindrance and the coordination ability of the 2-methoxy group. ${ }^{21}$ The reaction of $\beta$-naphthyl-substitubed styrene was sluggish; in this case, prolonging the

Georg Theme Verlag Stuttgart · New York - Synthesis 2019, 51, 240-250 


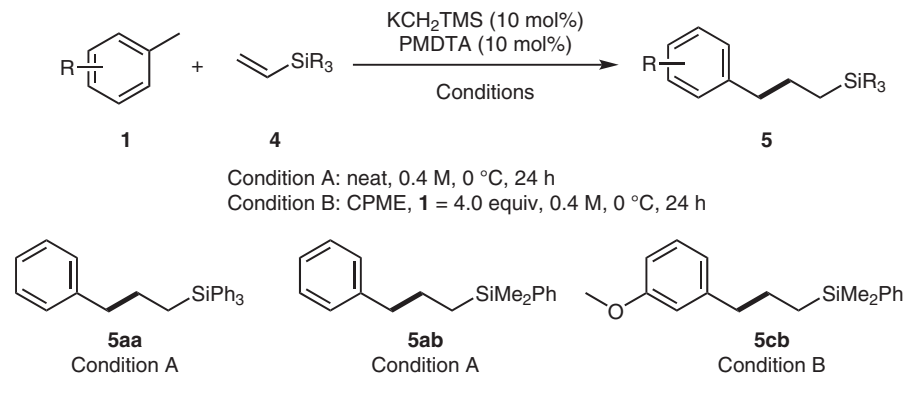

$78 \%$

$87 \%$

$85 \%$

Scheme 5 The addition reactions of alkylarenes with vinylsilanes

reaction time gave adduct 3ah in high yield with excellent regioselectivity for the $\alpha$-adduct. In addition to stilbene derivatives, the use of $\beta$-alkyl-substituted styrenes was also examined. Due to the lower electrophilicity and the presence of allylic hydrogen atoms that can be deprotonated, higher reaction temperature and $\mathrm{KO}$-Bu/LiTMP were applied to afford the $\beta$-adducts 3ai and 3aj in poor-to-good yields with complete regioselectivities.

Vinylsilanes were also suitable electrophiles for the catalytic addition reaction, ${ }^{22}$ because the $\alpha$-silyl anion, which is a reaction intermediate formed upon nucleophilic addition to vinylsilane, could deprotonate a benzylic hydrogen of alkylarene to produce a nucleophilic benzylic anion. The addition reaction of toluene with triphenyl- and phenyldimethylvinylsilanes proceeded smoothly in the presence of 10 mol\% $\mathrm{KCH}_{2}$ TMS and PMDTA to give alkylsilanes 5aa and $\mathbf{5 a b}$, respectively, in high yields. The reaction of $m$-methoxytoluene with phenyldimethylvinylsilane also proceeded to afford the product $\mathbf{5 c b}$ in good yield (Scheme 5). To gain insight into the mechanism of the reaction, the kinetic isotope effect was measured with toluene and toluene- $d_{8}$ (Scheme 6). The observed primary KIE value (5.3) indicated that deprotonation of a benzylic hydrogen from toluene was the rate-determining step.

The assumed reaction mechanism is shown in Scheme 7. First, $\mathrm{KCH}_{2} \mathrm{TMS}$ ligated with PMDTA deprotonates a benzylic hydrogen of the alkylarene to form a potassiumbenzyl species. Nucleophilic addition to the alkene occurs to produce an alkylpotassium species, which possess relatively strong basicity. This reaction intermediate then deprotonates another benzylic hydrogen of a second alkylarene to afford the products and the next nucleophilic species. Thereby, the addition reaction proceeds with only a catalytic amount of $\mathrm{KCH}_{2} \mathrm{TMS}$ and the ligand.

In summary, we have achieved alkylpotassiumcatalyzed addition reactions of alkylarenes with several alkenes. $\mathrm{KCH}_{2} \mathrm{TMS}$ with PMDTA as a catalytic species showed suitable reactivity and selectivity for the reaction, and allowed much milder reaction conditions and a broader substrate scope. Further investigations of alkylpotassiumcatalyzed reactions are under way in our laboratory.

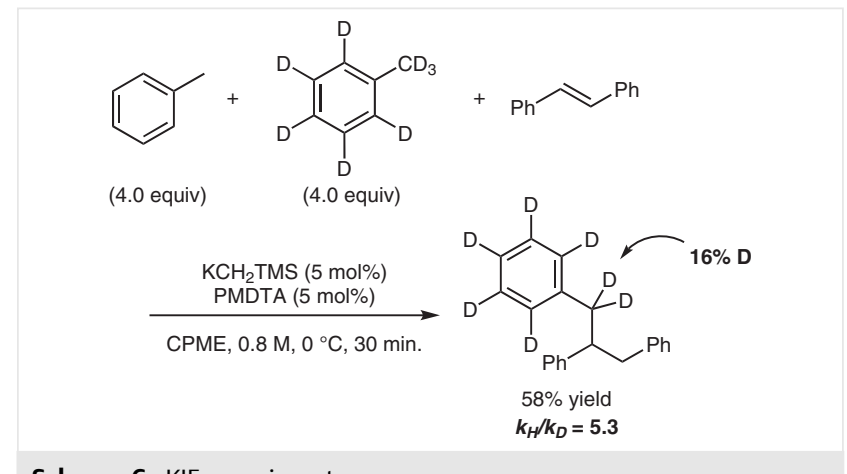

Scheme 6 KIE experiments

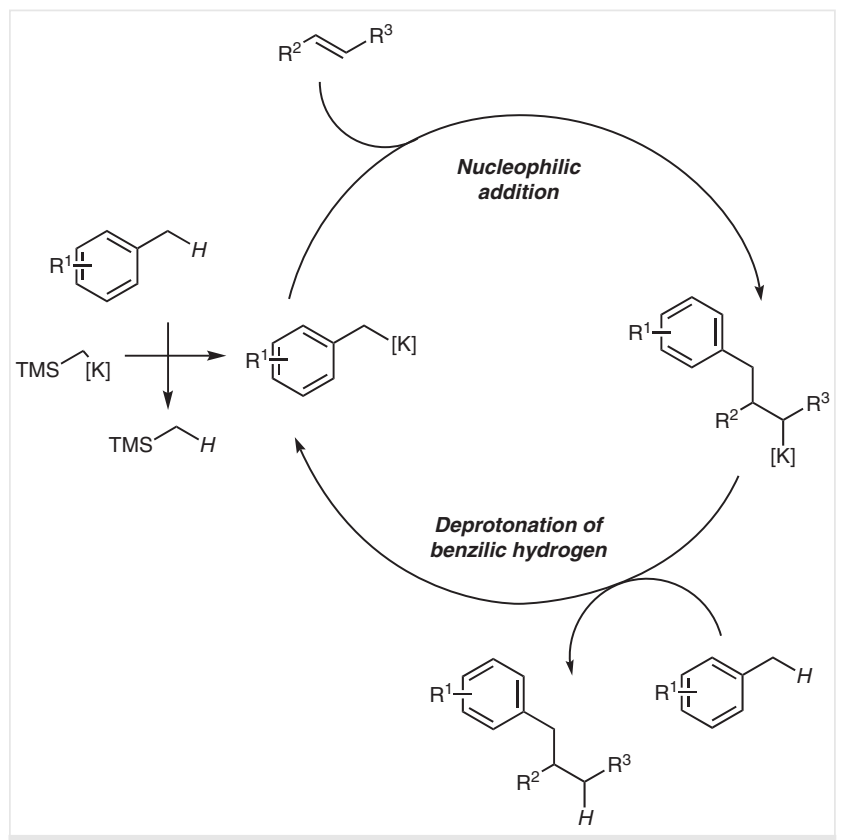

Scheme 7 Assumed reaction mechanism

${ }^{1} \mathrm{H}$ and ${ }^{13} \mathrm{C}$ NMR spectra were recorded with JEOL JNM-ECA500 and JNM-ECX600 spectrometers in $\mathrm{CDCl}_{3}$, unless otherwise noted. TMS served as internal standard $(\delta=0)$ for ${ }^{1} \mathrm{H}$ NMR, and $\mathrm{CDCl}_{3}$ served as internal standard $(\delta=77.0)$ for ${ }^{13} \mathrm{C}$ NMR. Benzotrifluoride (BTF) 
served as internal standard $(\delta=-63.72)$ for ${ }^{19} \mathrm{~F}$ NMR. IR spectra were recorded on a JASCO FT/IR-4200 spectrometer. Preparative TLC (PTLC) was carried out with Wakogel B-5F. KOt-Bu was purchased from Wako Pure Chemical Industrials, Ltd. Lithium 2,2,6,6-tetramethylpiperizide (LiTMP) was purchased from Aldrich Co., Ltd. (Trimethylsilyl)methylpotassium ( $\mathrm{KCH}_{2} \mathrm{TMS}$ ) was prepared according to a reported procedure. ${ }^{17}$ TMEDA and PMDTA were purchased from Tokyo Chemical Industry Co., Ltd. Heptane was purchased from Aldrich Co., Ltd. $\mathrm{Et}_{2} \mathrm{O}$ and $\mathrm{CPME}$ were purchased from Tokyo Chemical Industry Co., Ltd., and distilled just before use in the presence of benzophenone and Na. Alkylarenes were purchased from Tokyo Chemical Industry Co., Ltd., and distilled with $\mathrm{CaH}$. Electrophiles were prepared according to reported methods. Detailed information is provided in the Supporting Information.

\section{Catalytic Addition Reaction of Alkylarenes 1 with Alkenes 2 (Con- dition A); Propane-1,2,3-triyltribenzene (3aa); Typical Procedure (Scheme 3)}

$\mathrm{KCH}_{2}$ TMS (3.8 mg, $3.0 \times 10^{-2} \mathrm{mmol}$ ) and alkene 2a (540.4 mg, 3.0 $\mathrm{mmol}$ ) were placed in a flame-dried $20 \mathrm{~mL}$ flask inside a glove box filled with argon, and alkylarene $\mathbf{1 a}(7.5 \mathrm{~mL})$ and PMDTA $(6.3 \mu \mathrm{L}, 3.0 \times$ $10^{-2} \mathrm{mmol}$ ) were subsequently added at $-78{ }^{\circ} \mathrm{C}$ using a well-dried syringe, and the mixture was stirred for $24 \mathrm{~h}$ at $0{ }^{\circ} \mathrm{C}$. The reaction was quenched by adding $\mathrm{H}_{2} \mathrm{O}(2 \mathrm{~mL})$ and the aqueous phase was extracted with $\mathrm{CH}_{2} \mathrm{Cl}_{2}(3 \times 20 \mathrm{~mL})$. The combined organic layers were dried (anhyd $\mathrm{Na}_{2} \mathrm{SO}_{4}$ ). After filtration and concentration under reduced pressure, the crude product obtained was purified by flash column chromatography on silica gel (hexane $/ \mathrm{CH}_{2} \mathrm{Cl}_{2} 20: 1$ ) to afford the desired product 3aa; yield: $710.1 \mathrm{mg}(2.61 \mathrm{mmol}, 87 \%)$.

\section{Catalytic Addition Reaction of Alkylarenes 1 with Alkenes 2 (Con- dition B); [3-(2-Methoxyphenyl)propane-1,2-diyl]dibenzene (3ba); Typical Procedure (Scheme 3)}

$\mathrm{KCH}_{2}$ TMS (3.8 mg, $3.0 \times 10^{-2} \mathrm{mmol}$ ) and alkene $2 \mathrm{a}(271.0 \mathrm{mg}, 1.5$ $\mathrm{mmol}$ ) were placed in a flame-dried $10 \mathrm{~mL}$ flask inside a glove box filled with argon, and CPME $(0.75 \mathrm{~mL})$, alkylarene $\mathbf{1 b}(0.75 \mathrm{~mL}, 1.2 \times$ $10 \mathrm{mmol}, 4.0$ equiv) and PMDTA $\left(6.2 \mu \mathrm{L}, 3.0 \times 10^{-2} \mathrm{mmol}\right)$ were subsequently added at $-78{ }^{\circ} \mathrm{C}$ using a well-dried syringe, and the mixture was stirred for $18 \mathrm{~h}$ at $0{ }^{\circ} \mathrm{C}$. The reaction was quenched by adding $\mathrm{H}_{2} \mathrm{O}$ $(2 \mathrm{~mL})$ and the aqueous phase was extracted with $\mathrm{CH}_{2} \mathrm{Cl}_{2}(3 \times 20 \mathrm{~mL})$. The combined organic layers were dried (anhyd $\mathrm{Na}_{2} \mathrm{SO}_{4}$ ). After filtration and concentration under reduced pressure, the crude product obtained was purified by PTLC (hexane $/ \mathrm{CH}_{2} \mathrm{Cl}_{2} 8: 1 \times 3$ ) to afford the desired product 3ba; yield: $351.6 \mathrm{mg}(1.16 \mathrm{mmol}, 78 \%)$.

\section{Propane-1,2,3-triyltribenzene (3aa)}

Condition A; scale: $3.0 \mathrm{mmol}$; catalyst loading: $1 \mathrm{~mol} \%$; temperature: $0{ }^{\circ} \mathrm{C}$; time: $24 \mathrm{~h}$; colorless oil; yield: $710.1 \mathrm{mg}(87 \%) ; R_{f}=0.2$ (hexane/ $\mathrm{CH}_{2} \mathrm{Cl}_{2} 20: 1$ ).

IR (neat): 3061, 3027, 2924, 2853, 1601, 1495, 1449, 1075, $1031 \mathrm{~cm}^{-1}$. ${ }^{1} \mathrm{H}$ NMR $\left(\mathrm{CDCl}_{3}, 600 \mathrm{MHz}\right): \delta=7.14-7.11(6 \mathrm{H}, \mathrm{m}), 7.06-7.03(3 \mathrm{H}, \mathrm{m})$, $6.97(2 \mathrm{H}, \mathrm{d}, J=8.25 \mathrm{~Hz}), 6.92(4 \mathrm{H}, \mathrm{d}, J=8.25 \mathrm{~Hz}), 3.08-3.03(1 \mathrm{H}, \mathrm{m})$, $2.90(2 \mathrm{H}, \mathrm{dd}, J=13.74,6.18 \mathrm{~Hz}), 2.83(2 \mathrm{H}, \mathrm{dd}, J=13.75,8.25 \mathrm{~Hz})$.

${ }^{13} \mathrm{C}$ NMR $\left(\mathrm{CDCl}_{3}, 150 \mathrm{MHz}\right): \delta=144.22,140.45,129.11,128.08$, $128.03,127.88,126.10,125.79,49.87,42.44$.

HRMS (Dart): $m / z$ [M $\left.+\mathrm{NH}_{4}\right]^{+}$calcd for $\mathrm{C}_{21} \mathrm{H}_{24} \mathrm{~N}: 290.19033$; found: 290.19111.

\section{[3-(2-Methoxyphenyl)propane-1,2-diyl]dibenzene (3ba)}

Condition B; scale: $1.5 \mathrm{mmol}$; catalyst loading: $2 \mathrm{~mol} \%$; temperature: $0{ }^{\circ} \mathrm{C}$; time: $18 \mathrm{~h}$; colorless oil; yield: $351.6 \mathrm{mg}$ (78\%); $R_{f}=0.3$ (hexane $/ \mathrm{CH}_{2} \mathrm{Cl}_{2} 3: 1$ ).

IR (neat): 518, 601, 695, 749, 908, 1029, 1051, 1072, 1111, 1176, $1241,1438,1452,1492,1585,1600 \mathrm{~cm}^{-1}$.

${ }^{1} \mathrm{H} \mathrm{NMR}\left(\mathrm{CDCl}_{3}, 500 \mathrm{MHz}\right): \delta=7.14-7.09(9 \mathrm{H}, \mathrm{m}), 6.99(2 \mathrm{H}, \mathrm{d}, J=7.94$ $\mathrm{Hz}), 6.89(1 \mathrm{H}, \mathrm{d}, J=7.37 \mathrm{~Hz}), 6.77-6.74(2 \mathrm{H}, \mathrm{m}), 3.71(3 \mathrm{H}, \mathrm{s}), 3.23-$ $3.20(1 \mathrm{H}, \mathrm{m}), 3.02-2.99(2 \mathrm{H}, \mathrm{m}), 2.93-2.84(2 \mathrm{H}, \mathrm{m})$.

${ }^{13} \mathrm{C}$ NMR $\left(\mathrm{CDCl}_{3}, 125 \mathrm{MHz}\right): \delta=157.57,144.84,140.82,130.71$, $129.09,128.96,127.89,127.87,127.03,125.86,125.85,125.58$, $120.04,110.17,55.14,47.94,42.33,37.01$.

HRMS (DART): $m / z[\mathrm{M}+\mathrm{H}]^{+}$calcd for $\mathrm{C}_{22} \mathrm{H}_{23} \mathrm{O}$ : 303.17489; found: 303.17516.

\section{[3-(3-Methoxyphenyl)propane-1,2-diyl]dibenzene (3ca)}

Condition A; scale: $3.0 \mathrm{mmol}$; catalyst loading: $1 \mathrm{~mol} \%$; temperature: $0{ }^{\circ} \mathrm{C}$; time: $18 \mathrm{~h}$; colorless oil; yield: $782.5 \mathrm{mg}(86 \%) ; R_{f}=0.1$ (hexane $/ \mathrm{CH}_{2} \mathrm{Cl}_{2} 3: 1$ ).

IR (neat): 521, 546, 694, 739, 758, 772, 1042, 1072, 1152, 1260, 1436, $1452,1465,1488,1583,1600 \mathrm{~cm}^{-1}$.

${ }^{1} \mathrm{H} \mathrm{NMR}\left(\mathrm{CDCl}_{3}, 500 \mathrm{MHz}\right): \delta=7.13-7.08(4 \mathrm{H}, \mathrm{m}), 7.06-7.00(3 \mathrm{H}, \mathrm{m})$, $6.97(2 \mathrm{H}, \mathrm{d}, J=7.56 \mathrm{~Hz}), 6.92(2 \mathrm{H}, \mathrm{d}, J=7.56 \mathrm{~Hz}), 6.59-6.58(1 \mathrm{H}, \mathrm{m})$, $6.53(1 \mathrm{H}, \mathrm{d}, J=7.56 \mathrm{~Hz}), 6.43(1 \mathrm{H}, \mathrm{s}), 3.59(3 \mathrm{H}, \mathrm{s}), 3.08-3.03(1 \mathrm{H}, \mathrm{m})$, 2.91-2.79 (4 H, m).

${ }^{13} \mathrm{C}$ NMR $\left(\mathrm{CDCl}_{3}, 125 \mathrm{MHz}\right): \delta=159.29,144.23,142.04,140.41$, $129.11,128.95,128.09,128.02,127.88,126.11,125.79,121.55$, 114.74, 111.27, 55.01, 49.72, 42.45, 42.42.

HRMS (DART): $m / z[\mathrm{M}+\mathrm{H}]^{+}$calcd for $\mathrm{C}_{22} \mathrm{H}_{23} \mathrm{O}$ : 303.17489; found: 303.17370.

[3-(3-Methoxy-5-methylphenyl)propane-1,2-diyl]dibenzene (3da) Condition B; scale: $0.6 \mathrm{mmol}$; catalyst loading: $5 \mathrm{~mol} \%$; temperature: $0{ }^{\circ} \mathrm{C}$; time: $18 \mathrm{~h}$; colorless oil; yield: $124.8 \mathrm{mg}(66 \%) ; R_{f}=0.2$ (hexane $/ \mathrm{CH}_{2} \mathrm{Cl}_{2} 4: 1$ ).

IR (neat): 494, 551, 612, 695, 739, 758, 781, 833, 925, 963, 1031, 1066 , $1151,1166,1192,1290,1323,1452,1493,1593 \mathrm{~cm}^{-1}$.

${ }^{1} \mathrm{H} \mathrm{NMR}\left(\mathrm{CDCl}_{3}, 500 \mathrm{MHz}\right): \delta=7.14-7.01(6 \mathrm{H}, \mathrm{m}), 6.98(2 \mathrm{H}, \mathrm{d}, J=7.94$ $\mathrm{Hz}), 6.91(2 \mathrm{H}, \mathrm{d}, J=7.94 \mathrm{~Hz}), 6.41(1 \mathrm{H}, \mathrm{s}), 6.37(1 \mathrm{H}, \mathrm{s}), 6.24(1 \mathrm{H}, \mathrm{s})$, 3.58 ( $3 \mathrm{H}, \mathrm{s}), 3.07-3.01(1 \mathrm{H}, \mathrm{m}), 2.90(1 \mathrm{H}, \mathrm{dd}, J=6.61,3.31 \mathrm{~Hz}), 2.84-$ $2.75(3 \mathrm{H}, \mathrm{m}), 2.16(3 \mathrm{H}, \mathrm{s})$.

${ }^{13} \mathrm{C}$ NMR $\left(\mathrm{CDCl}_{3}, 125 \mathrm{MHz}\right): \delta=159.27,144.34,141.76,140.44$, 138.87, 129.10, 128.06, 127.99, 127.87, 126.06, 125.74, 122.49, $112.15,111.69,54.98,49.62,42.47,42.31,21.47$.

HRMS (DART): $m / z[\mathrm{M}+\mathrm{H}]^{+}$calcd for $\mathrm{C}_{23} \mathrm{H}_{25} \mathrm{O}$ : 317.19504; found: 317.19106.

\section{[3-(2-Fluorophenyl)propane-1,2-diyl]dibenzene (3ea)}

Condition B; scale: $0.3 \mathrm{mmol}$; catalyst loading: $10 \mathrm{~mol} \%$; temperature: $-10{ }^{\circ} \mathrm{C}$; time: $24 \mathrm{~h}$; colorless oil; yield: $40.4 \mathrm{mg}$ (46\%); $R_{f}=0.3$ (hexane $/ \mathrm{CH}_{2} \mathrm{Cl}_{2}$ 9:1).

IR (neat): 521, 601, 695, 752, 846, 1031, 1072, 1098, 1181, 1228, $1452,1490,1583,1600 \mathrm{~cm}^{-1}$.

${ }^{1} \mathrm{H}$ NMR $\left(\mathrm{CDCl}_{3}, 500 \mathrm{MHz}\right): \delta=7.12-7.10(4 \mathrm{H}, \mathrm{m}), 7.06-6.98(5 \mathrm{H}, \mathrm{m})$, $6.93(2 \mathrm{H}, \mathrm{t}, J=4.25 \mathrm{~Hz}), 6.88-6.83(3 \mathrm{H}, \mathrm{m}), 3.14-3.11(1 \mathrm{H}, \mathrm{m}), 2.99$ $(1 \mathrm{H}, \mathrm{dd}, J=6.61,3.31 \mathrm{~Hz}), 2.92-2.89(2 \mathrm{H}, \mathrm{m}), 2.85-2.80(1 \mathrm{H}, \mathrm{m})$. 
${ }^{13} \mathrm{C}$ NMR $\left(\mathrm{CDCl}_{3}, 125 \mathrm{MHz}\right): \delta=162.15\left(J_{\mathrm{C}, \mathrm{F}}=245.35 \mathrm{~Hz}\right), 143.87$, $140.26,131.32\left(J_{C, F}=5.98 \mathrm{~Hz}\right), 129.04,128.07,128.02,127.75,127.58$ $\left(J_{C, F}=7.18 \mathrm{~Hz}\right), 127.37\left(J_{C, F}=15.56 \mathrm{~Hz}\right), 126.17,125.80,123.59\left(J_{C, F}=\right.$ $3.59 \mathrm{~Hz}), 115.11\left(J_{\mathrm{C}, \mathrm{F}}=22.73 \mathrm{~Hz}\right), 48.41,42.47,35.65$.

${ }^{19} \mathrm{~F} \mathrm{NMR}\left(\mathrm{CDCl}_{3}, 465 \mathrm{MHz}\right): \delta=-119.10$.

HRMS (DART): $m / z\left[\mathrm{M}+\mathrm{NH}_{4}\right]^{+}$calcd for $\mathrm{C}_{21} \mathrm{H}_{23} \mathrm{FN}$ : 308.18145; found: 308.17991.

\section{[3-(3-Fluorophenyl)propane-1,2-diyl]dibenzene (3fa)}

Condition B; scale: $0.3 \mathrm{mmol}$; catalyst loading: $10 \mathrm{~mol} \%$; temperature: $-10{ }^{\circ} \mathrm{C}$; time: $24 \mathrm{~h}$; colorless oil; yield: $66.2 \mathrm{mg}(76 \%) ; R_{f}=0.3$ (hexane $/ \mathrm{CH}_{2} \mathrm{Cl}_{2}$ 9:1)

IR (neat): 521, 548, 601, 626, 696, 744, 758, 778, 881, 909, 936, 959, $1031,1072,1139,1249,1452,1486,1588,1602,1615 \mathrm{~cm}^{-1}$.

${ }^{1} \mathrm{H}$ NMR $\left(\mathrm{CDCl}_{3}, 500 \mathrm{MHz}\right): \delta=7.21-7.09(7 \mathrm{H}, \mathrm{m}), 7.04-7.00(4 \mathrm{H}, \mathrm{m})$, $6.80(1 \mathrm{H}, \mathrm{td}, J=8.50,2.27 \mathrm{~Hz}), 6.74(1 \mathrm{H}, \mathrm{d}, J=7.37 \mathrm{~Hz}), 6.67(1 \mathrm{H}, \mathrm{d}, J$ = 9.64 Hz), 3.13-3.10 $(1 \mathrm{H}, \mathrm{m}), 2.95-2.90(4 \mathrm{H}, \mathrm{m})$.

${ }^{13} \mathrm{C}$ NMR $\left(\mathrm{CDCl}_{3}, 125 \mathrm{MHz}\right): \delta=163.60\left(J_{\mathrm{C}, \mathrm{F}}=246.56 \mathrm{~Hz}\right), 143.74$, $143.05\left(J_{C, F}=7.18 \mathrm{~Hz}\right), 140.18,129.38\left(J_{C, F}=8.38 \mathrm{~Hz}\right), 129.07,128.17$, $128.11,127.77,126.28,125.91,124.76\left(J_{C, F}=2.39 \mathrm{~Hz}\right), 115.90\left(J_{C, F}=\right.$ $20.35 \mathrm{~Hz}), 112.75\left(J_{C, \mathrm{~F}}=20.35 \mathrm{~Hz}\right), 49.70,42.56,42.01$.

${ }^{19} \mathrm{~F} \mathrm{NMR}\left(\mathrm{CDCl}_{3}, 465 \mathrm{MHz}\right): \delta=-115.07$.

HRMS (DART): $m / z\left[\mathrm{M}+\mathrm{NH}_{4}\right]^{+}$calcd for $\mathrm{C}_{21} \mathrm{H}_{23} \mathrm{FN}$ : 308.18145 ; found: 308.18183

\section{[3-(o-Tolyl)propane-1,2-diyl]dibenzene (3ga)}

Condition A; scale: $1.0 \mathrm{mmol}$; catalyst loading: $2 \mathrm{~mol} \%$; temperature: $0{ }^{\circ} \mathrm{C}$; time: $24 \mathrm{~h}$; colorless oil; yield: $257.2 \mathrm{mg}(90 \%) ; R_{f}=0.3$ (hexane $/ \mathrm{CH}_{2} \mathrm{Cl}_{2}$ 9:1)

IR (neat): 454, 516, 541, 562, 601, 695, 738, 759, 1029, 1072, 1452 , $1493,1600 \mathrm{~cm}^{-1}$.

${ }^{1} \mathrm{H} \mathrm{NMR}\left(\mathrm{CDCl}_{3}, 500 \mathrm{MHz}\right): \delta=7.21-7.10(6 \mathrm{H}, \mathrm{m}), 7.07-6.97(7 \mathrm{H}, \mathrm{m})$, $6.86(1 \mathrm{H}, \mathrm{d}, J=7.37 \mathrm{~Hz}), 3.08-2.94(4 \mathrm{H}, \mathrm{m}), 2.84(1 \mathrm{H}, \mathrm{dd}, J=13.89$, $8.22 \mathrm{~Hz}), 2.09(3 \mathrm{H}, \mathrm{s})$.

${ }^{13} \mathrm{C}$ NMR $\left(\mathrm{CDCl}_{3}, 125 \mathrm{MHz}\right): \delta=144.50,140.58,138.65,136.16$, $130.06,129.91,129.11,128.09,128.04,127.78,126.11,125.90$, $125.80,125.46,48.88,42.34,39.83,19.28$

HRMS (DART): $m / z$ [M $\left.+\mathrm{NH}_{4}\right]^{+}$calcd for $\mathrm{C}_{22} \mathrm{H}_{26} \mathrm{~N}: 304.20652$; found: 304.20853.

\section{[3-(m-Tolyl)propane-1,2-diyl]dibenzene (3ha)}

Condition A; scale: $2.0 \mathrm{mmol}$; catalyst loading: $1 \mathrm{~mol} \%$; temperature: $0{ }^{\circ} \mathrm{C}$; time: $24 \mathrm{~h}$; colorless oil; yield: $482.9 \mathrm{mg}(84 \%) ; R_{f}=0.3$ (hexane $/ \mathrm{CH}_{2} \mathrm{Cl}_{2}$ 19:1).

IR (neat): 445, 518, 551, 601, 695, 739, 758, 772, 1031, 1072, 1452, $1493,1602 \mathrm{~cm}^{-1}$.

${ }^{1} \mathrm{H} \mathrm{NMR}\left(\mathrm{CDCl}_{3}, 500 \mathrm{MHz}\right): \delta=7.20-7.03(9 \mathrm{H}, \mathrm{m}), 6.97(2 \mathrm{H}, \mathrm{d}, J=7.94$ $\mathrm{Hz}), 6.93(1 \mathrm{H}, \mathrm{d}, J=7.37 \mathrm{~Hz}), 6.81-6.80(2 \mathrm{H}, \mathrm{m}), 3.15-3.09(1 \mathrm{H}, \mathrm{m})$, 2.99-2.85 (4 H, m), $2.24(3 \mathrm{H}, \mathrm{s})$.

${ }^{13} \mathrm{C}$ NMR $\left(\mathrm{CDCl}_{3}, 125 \mathrm{MHz}\right): \delta=144.36,140.50,140.36,137.50$, $129.95,129.11,128.05,128.00,127.90,127.87,126.54,126.12$, $126.06,125.75,49.77,42.43,42.34,21.35$.

HRMS (DART): $m / z$ [M $\left.+\mathrm{NH}_{4}\right]^{+}$calcd for $\mathrm{C}_{22} \mathrm{H}_{26} \mathrm{~N}$ : 304.20652; found: 304.20651 .

\section{[3-(p-Tolyl)propane-1,2-diyl]dibenzene (3ia)}

Condition A; scale: $1.5 \mathrm{mmol}$; catalyst loading: $2 \mathrm{~mol} \%$; temperature: $25{ }^{\circ} \mathrm{C}$; time: $42 \mathrm{~h}$; colorless oil; yield: $275.3 \mathrm{mg}(64 \%) ; R_{f}=0.4$ (hexane $/ \mathrm{CH}_{2} \mathrm{Cl}_{2}$ 9:1).

IR (neat): 599, 696, 731, 746, 772, 908, 1076, 1029, 1452, 1495, 1509, $1596 \mathrm{~cm}^{-1}$.

${ }^{1} \mathrm{H}$ NMR $\left(\mathrm{CDCl}_{3}, 500 \mathrm{MHz}\right): \delta=7.12-7.02(6 \mathrm{H}, \mathrm{m}), 6.97-6.96(2 \mathrm{H}, \mathrm{m})$, 6.91-6.89 (4 H, m), $6.81(2 \mathrm{H}, \mathrm{d}, J=7.94 \mathrm{~Hz}), 3.06-3.00(1 \mathrm{H}, \mathrm{m}), 2.91-$ $2.78(4 \mathrm{H}, \mathrm{m}), 2.18(3 \mathrm{H}, \mathrm{s})$.

${ }^{13} \mathrm{C}$ NMR $\left(\mathrm{CDCl}_{3}, 125 \mathrm{MHz}\right): \delta=144.35,140.50,137.31,135.16$, $129.11,128.95,128.74,128.05,127.99,127.89,126.03,125.73,49.87$, 42.40, 41.97, 20.98

HRMS (DART): $m / z$ [M $\left.+\mathrm{NH}_{4}\right]^{+}$calcd for $\mathrm{C}_{22} \mathrm{H}_{26} \mathrm{~N}: 304.20652$; found: 304.20738 .

\section{[3-(4-Isopropylphenyl)propane-1,2-diyl]dibenzene (3ja)}

Condition B; scale: $0.6 \mathrm{mmol}$; catalyst loading: $5 \mathrm{~mol} \%$; temperature: $25{ }^{\circ} \mathrm{C}$; time: $18 \mathrm{~h}$; colorless oil; yield: $109.7 \mathrm{mg}(58 \%) ; R_{f}=0.2$ (hexane $/ \mathrm{CH}_{2} \mathrm{Cl}_{2} 16: 1$ ).

IR (neat): 522, 548, 582, 695, 732, 758, 816, 1019, 1031, 1055, 1072, $1362,1382,1418,1452,1495,1512,1602 \mathrm{~cm}^{-1}$.

${ }^{1} \mathrm{H} \mathrm{NMR}\left(\mathrm{CDCl}_{3}, 500 \mathrm{MHz}\right): \delta=7.13-6.97(10 \mathrm{H}, \mathrm{m}), 6.89-6.87(4 \mathrm{H}$, m), 3.09-3.03 $(1 \mathrm{H}, \mathrm{m}), 2.92-2.97(5 \mathrm{H}, \mathrm{m}), 1.12(6 \mathrm{H}, \mathrm{d}, J=6.80 \mathrm{~Hz})$.

${ }^{13} \mathrm{C}$ NMR $\left(\mathrm{CDCl}_{3}, 125 \mathrm{MHz}\right): \delta=146.26,144.48,140.51,137.72$, $129.09,128.97,128.06,127.96,127.88,126.10,126.03,125.70,49.66$, 42.33, 42.00, 33.60, 24.01 .

HRMS (DART): $m / z[M+H]^{+}$calcd for $\mathrm{C}_{24} \mathrm{H}_{27}: 315.21128$; found: 315.21292

\section{(Butane-1,2,3-triyl)tribenzene (Major Diastereomer, 3ka-M)}

Condition A; scale: $0.3 \mathrm{mmol}$; catalyst loading: $10 \mathrm{~mol} \%$; temperature: $0{ }^{\circ} \mathrm{C}$; time: $24 \mathrm{~h}$; white solid; yield: $55.5 \mathrm{mg}$ (65\%); $\mathrm{mp} 92-93{ }^{\circ} \mathrm{C}$; $R_{f}=0.2$ (hexane $/ \mathrm{CH}_{2} \mathrm{Cl}_{2} 9: 1$ ).

IR (neat): 564, 696, 739, 772, 789, 795, 1395, 1452, 1495, $1509 \mathrm{~cm}^{-1}$. ${ }^{1} \mathrm{H}$ NMR $\left(\mathrm{CDCl}_{3}, 500 \mathrm{MHz}\right): \delta=7.36(2 \mathrm{H}, \mathrm{t}, J=7.65 \mathrm{~Hz}), 7.30-7.20(5$ $\mathrm{H}, \mathrm{m}), 7.15-7.14(1 \mathrm{H}, \mathrm{m}), 7.06-7.00(5 \mathrm{H}, \mathrm{m}), 6.72(2 \mathrm{H}, \mathrm{d}, J=7.37 \mathrm{~Hz})$, 3.04-2.98 (1 H, m), $2.93(1 \mathrm{H}, \mathrm{dt}, J=10.34,5.17 \mathrm{~Hz}), 2.80(1 \mathrm{H}, \mathrm{dd}, J=$ 13.32, 3.68 Hz), $2.62(1 \mathrm{H}, \mathrm{dd}, J=13.32,10.49 \mathrm{~Hz}), 1.02(3 \mathrm{H}, \mathrm{d}, J=6.80$ $\mathrm{Hz})$.

${ }^{13} \mathrm{C}$ NMR $\left(\mathrm{CDCl}_{3}, 500 \mathrm{MHz}\right): \delta=146.55,143.08,140.88,128.80$, $128.57,128.51,127.99,127.73,127.61,126.22,126.08,125.38,55.64$, $45.72,41.15,20.80$

HRMS (DART): $m / z$ [M $\left.+\mathrm{NH}_{4}\right]^{+}$calcd for $\mathrm{C}_{22} \mathrm{H}_{26} \mathrm{~N}: 304.20652$; found: 304.20829.

\section{(Butane-1,2,3-triyl)tribenzene (Minor Diastereomer, 3ka-m)}

Condition A; scale: $0.3 \mathrm{mmol}$; catalyst loading: $10 \mathrm{~mol} \%$; temperature: $0{ }^{\circ} \mathrm{C}$; time: $24 \mathrm{~h}$; colorless oil; yield: $29.2 \mathrm{mg}$ (34\%); $R_{f}=0.1$ (hexane $/ \mathrm{CH}_{2} \mathrm{Cl}_{2}$ 9:1).

IR (neat): 498, 524, 542, 621, 694, 744, 761, 1031, 1069, 1375, 1450, $1493,1602 \mathrm{~cm}^{-1}$.

${ }^{1} \mathrm{H} \mathrm{NMR}\left(\mathrm{CDCl}_{3}, 500 \mathrm{MHz}\right): \delta=7.10(9 \mathrm{H}, \mathrm{m}), 6.97(4 \mathrm{H}, \mathrm{t}, J=7.65 \mathrm{~Hz})$, $6.87(2 \mathrm{H}, \mathrm{d}, J=6.80 \mathrm{~Hz}), 3.16-3.11(3 \mathrm{H}, \mathrm{m}), 2.91-2.86(1 \mathrm{H}, \mathrm{m}), 1.38$ ( $3 \mathrm{H}, \mathrm{d}, J=6.24 \mathrm{~Hz}$ ).

${ }^{13} \mathrm{C}$ NMR $\left(\mathrm{CDCl}_{3}, 500 \mathrm{MHz}\right): \delta=144.85,142.23,140.78,129.05$, $129.00,128.21,127.93,127.69,127.43,125.81,125.79,125.55,54.38$, $44.74,38.71,19.31$. 
HRMS (DART): $m / z$ [M $\left.+\mathrm{NH}_{4}\right]^{+}$calcd for $\mathrm{C}_{22} \mathrm{H}_{26} \mathrm{~N}: 304.20652$; found: 304.20517.

\section{4,4'-(3-Phenylpropane-1,2-diyl)bis(tert-butylbenzene) (3ab)}

Condition A; scale: $0.3 \mathrm{mmol}$; catalyst loading: $10 \mathrm{~mol} \%$; temperature: $0{ }^{\circ} \mathrm{C}$; time: $18 \mathrm{~h}$; white solid; yield: $115.7 \mathrm{mg}(\sim 100 \%)$; mp 82$84{ }^{\circ} \mathrm{C} ; R_{f}=0.5$ (hexane $/ \mathrm{CH}_{2} \mathrm{Cl}_{2} 4: 1$ ).

IR (neat): 698, 729, 746, 774, 789, 1395, 1453, 1495, 1509, $1596 \mathrm{~cm}^{-1}$. ${ }^{1} \mathrm{H}$ NMR $\left(\mathrm{CDCl}_{3}, 500 \mathrm{MHz}\right): \delta=7.15-7.12(4 \mathrm{H}, \mathrm{m}), 7.08-7.06(2 \mathrm{H}, \mathrm{m})$, 7.03-7.00 (1 H, m), 6.94-6.88 (6 H, m), 3.08-3.03 (1 H, m), 2.87-2.75 $(4 \mathrm{H}, \mathrm{m}), 1.20(9 \mathrm{H}, \mathrm{s}), 1.20(9 \mathrm{H}, \mathrm{s})$.

${ }^{13} \mathrm{C}$ NMR $\left(\mathrm{CDCl}_{3}, 125 \mathrm{MHz}\right): \delta=148.72,148.46,141.62,140.73$, 137.61, 129.14, 128.73, 127.92, 127.35, 125.62, 124.94, 124.92, 48.73, 42.10, 41.74, 34.31, 34.30, 31.39, 31.38

HRMS (DART): $m / z[\mathrm{M}+\mathrm{H}]^{+}$calcd for $\mathrm{C}_{29} \mathrm{H}_{37}: 385.28953$; found: 385.29087.

\section{3,3'-(3-Phenylpropane-1,2-diyl)bis(methoxybenzene) (3ac)}

Condition A; scale: $0.3 \mathrm{mmol}$; catalyst loading: $10 \mathrm{~mol} \%$; temperature: $0{ }^{\circ} \mathrm{C}$; time: $18 \mathrm{~h}$; colorless oil; yield: $84.8 \mathrm{mg}(85 \%) ; R_{f}=0.1$ (hexane $/ \mathrm{CH}_{2} \mathrm{Cl}_{2} 3: 2$ ).

IR (neat): 474, 504, 571, 695, 741, 754, 776, 872, 1042, 1152, 1256, $1286,1315,1435,1452,1486,1583,1599 \mathrm{~cm}^{-1}$.

${ }^{1} \mathrm{H} \mathrm{NMR}\left(\mathrm{CDCl}_{3}, 500 \mathrm{MHz}\right): \delta=7.24-7.21(2 \mathrm{H}, \mathrm{m}), 7.16-7.15(3 \mathrm{H}, \mathrm{m})$, $7.05(2 \mathrm{H}, \mathrm{d}, J=7.94 \mathrm{~Hz}), 6.72(3 \mathrm{H}, \mathrm{d}, J=7.94 \mathrm{~Hz}), 6.67(1 \mathrm{H}, \mathrm{d}, J=7.37$ $\mathrm{Hz}), 6.63(1 \mathrm{H}, \mathrm{s}), 6.58(1 \mathrm{H}, \mathrm{s}), 3.74(3 \mathrm{H}, \mathrm{s}), 3.73(3 \mathrm{H}, \mathrm{s}), 3.19-3.13(1$ $\mathrm{H}, \mathrm{m}), 2.99-2.93(4 \mathrm{H}, \mathrm{m})$.

${ }^{13} \mathrm{C}$ NMR $\left(\mathrm{CDCl}_{3}, 125 \mathrm{MHz}\right): \delta=159.30,159.27,145.93,141.99$, $140.36,129.08,129.00,128.96,128.02,125.79,121.53,120.26$, $114.73,113.72,111.31,111.22,55.04,55.00,49.68,42.32,42.28$.

HRMS (DART): $m / z[\mathrm{M}+\mathrm{H}]^{+}$calcd for $\mathrm{C}_{23} \mathrm{H}_{25} \mathrm{O}_{2}$ : 333.18545; found: 333.18379

\section{4,4'-(3-Phenylpropane-1,2-diyl)bis(methoxybenzene) (3ad)}

Condition A; scale: $0.4 \mathrm{mmol}$; catalyst loading: $10 \mathrm{~mol} \%$; KOt-Bu and LiTMP were used instead of $\mathrm{KCH}_{2} \mathrm{TMS}$; temperature: $60{ }^{\circ} \mathrm{C}$; time: 24 h; colorless oil; yield: $137.2 \mathrm{mg}(\sim 100 \%) ; R_{f}=0.3$ (hexane $/ \mathrm{CH}_{2} \mathrm{Cl}_{2} 2: 1$ ). IR (neat): 3060, 3028, 3001, 2927, 2836, 1610, 1584, 1511, 1459, $1298,1178,1107,1036 \mathrm{~cm}^{-1}$.

${ }^{1} \mathrm{H} \mathrm{NMR}\left(\mathrm{CDCl}_{3}, 500 \mathrm{MHz}\right): \delta=7.18-7.16(2 \mathrm{H}, \mathrm{m}), 7.11-7.10(1 \mathrm{H}, \mathrm{m})$, $6.98(2 \mathrm{H}, \mathrm{d}, J=6.80 \mathrm{~Hz}), 6.93(2 \mathrm{H}, \mathrm{d}, J=8.50 \mathrm{~Hz}), 6.89(2 \mathrm{H}, \mathrm{d}, J=8.50$ $\mathrm{Hz}), 6.74-6.72(4 \mathrm{H}, \mathrm{m}), 3.73(3 \mathrm{H}, \mathrm{s}), 3.73(3 \mathrm{H}, \mathrm{s}), 3.06-3.01(1 \mathrm{H}, \mathrm{m})$, $2.96-2.78(4 \mathrm{H}, \mathrm{m})$.

${ }^{13} \mathrm{C}$ NMR $\left(\mathrm{CDCl}_{3}, 125 \mathrm{MHz}\right): \delta=157.75,157.63,140.64,136.35$, 132.60, 129.99, 129.10, 128.72, 127.98, 125.68, 113.40, 113.39, 55.09, $55.06,49.15,42.52,41.72$.

HRMS (DART): $m / z[\mathrm{M}+\mathrm{H}]^{+}$calcd for $\mathrm{C}_{23} \mathrm{H}_{25} \mathrm{O}_{2}: 333.18491$; found: 333.18418.

\section{1,1'-(3-Phenylpropane-1,2-diyl)dinaphthalene (3ae)}

Condition A; scale: $0.4 \mathrm{mmol}$; catalyst loading: $10 \mathrm{~mol} \%$; temperature: $0{ }^{\circ} \mathrm{C}$; time: $48 \mathrm{~h}$; colorless oil; yield: $113.2 \mathrm{mg}$ (76\%); $R_{f}=0.2$ (hexane $/ \mathrm{CH}_{2} \mathrm{Cl}_{2}$ 9:1).

IR (neat): 698, 729, 772, 908, 1395, 1452, 1495, 1029, $1596 \mathrm{~cm}^{-1}$.
${ }^{1} \mathrm{H} \mathrm{NMR}\left(\mathrm{CDCl}_{3}, 500 \mathrm{MHz}\right): \delta=7.79-7.77(3 \mathrm{H}, \mathrm{m}), 7.67(2 \mathrm{H}, \mathrm{d}, J=8.50$ $\mathrm{Hz}), 7.58(2 \mathrm{H}, \mathrm{d}, J=7.94 \mathrm{~Hz}), 7.40(4 \mathrm{H}, \mathrm{tt}, J=24.37,10.11 \mathrm{~Hz}), 7.20-$ $7.02(8 \mathrm{H}, \mathrm{m}), 4.34-4.32(1 \mathrm{H}, \mathrm{m}), 3.62-3.60(1 \mathrm{H}, \mathrm{m}), 3.44-3.42(1 \mathrm{H}$, $\mathrm{m}), 3.16-3.14(2 \mathrm{H}, \mathrm{m})$.

${ }^{13} \mathrm{C}$ NMR $\left(\mathrm{CDCl}_{3}, 125 \mathrm{MHz}\right): \delta=141.28,140.33,136.19,133.79$, $132.04,129.24,128.75,128.65,128.63,128.10,126.96,126.65$, $126.59,125.96,125.70,125.43,125.40,125.24,125.13,125.10$, 125.07, 123.57, 123.52, 122.62, 42.61, 41.08, 38.78.

HRMS (DART): $m / z[\mathrm{M}+\mathrm{H}]^{+}$calcd for $\mathrm{C}_{29} \mathrm{H}_{25}: 373.19563$; found: 373.19747.

\section{[2-(4-Methoxyphenyl)propane-1,3-diyl]dibenzene (3af)}

Condition A; scale: $0.6 \mathrm{mmol}$; catalyst loading: $5 \mathrm{~mol} \%$; temperature: $0{ }^{\circ} \mathrm{C}$; time: $24 \mathrm{~h}$; colorless oil; yield: $174.9 \mathrm{mg}(96 \%) ; \alpha: \beta=1: 12 ; R_{f}=$ 0.1 (hexane $/ \mathrm{CH}_{2} \mathrm{Cl}_{2} 4: 1$ ).

IR (neat): 598, 696, 746, 772, 821, 908, 1031, 1029, 1109, 1176, 1243 , $1300,1395,1452,1495,1510 \mathrm{~cm}^{-1}$.

${ }^{1} \mathrm{H}$ NMR $\left(\mathrm{CDCl}_{3}, 500 \mathrm{MHz}\right): \delta=7.20-7.16(4 \mathrm{H}, \mathrm{m}), 7.13-7.11(2 \mathrm{H}, \mathrm{m})$, 7.00-6.99 (4 H, m), 6.95-6.94 (2 H, m), 6.74-6.73 (2 H, m), $3.74(3 \mathrm{H}$, s), 3.10-3.06 $(1 \mathrm{H}, \mathrm{m}), 2.95(2 \mathrm{H}, \mathrm{dd}, J=6.61,3.31 \mathrm{~Hz}), 2.86(2 \mathrm{H}, \mathrm{dd}, J=$ $13.32,8.22 \mathrm{~Hz})$.

${ }^{13} \mathrm{C}$ NMR $\left(\mathrm{CDCl}_{3}, 125 \mathrm{MHz}\right): \delta=157.77,140.56,136.24,129.11$, $128.70,128.01,125.73,113.42,55.10,48.99,42.62$.

HRMS (DART): $m / z[M+H]^{+}$calcd for $\mathrm{C}_{22} \mathrm{H}_{23} \mathrm{O}$ : 303.17489; found: 303.17435.

\section{1-Methoxy-2-[2-(4-methoxyphenyl)-3-phenylpropyl]benzene (3bf)}

Condition B; scale: $0.6 \mathrm{mmol}$; catalyst loading: $5 \mathrm{~mol} \%$; temperature: $0{ }^{\circ} \mathrm{C}$; time: $18 \mathrm{~h}$; colorless oil; yield: $173.6 \mathrm{mg}(87 \%) ; \alpha: \beta=1: 12 ; R_{f}=$ 0.1 (hexane $/ \mathrm{CH}_{2} \mathrm{Cl}_{2} 4: 1$ ).

IR (neat): 546, 601, 698, 748, 824, 1031, 1105, 1176, 1239, 1438, $1492,1510,1585 \mathrm{~cm}^{-1}$.

${ }^{1} \mathrm{H} \mathrm{NMR}\left(\mathrm{CDCl}_{3}, 500 \mathrm{MHz}\right): \delta=7.15-7.07(4 \mathrm{H}, \mathrm{m}), 6.99-6.93(4 \mathrm{H}, \mathrm{m})$, $6.89(1 \mathrm{H}, \mathrm{d}, J=7.37 \mathrm{~Hz}), 6.77-6.68(4 \mathrm{H}, \mathrm{m}), 3.70(3 \mathrm{H}, \mathrm{s}), 3.70(3 \mathrm{H}, \mathrm{s})$, 3.20-3.14 (1 H, m), 3.00-2.96 (2 H, m), 2.87-2.83 (2 H, m).

${ }^{13} \mathrm{C}$ NMR $\left(\mathrm{CDCl}_{3}, 125 \mathrm{MHz}\right): \delta=157.59,157.51,140.89,136.87$, $130.70,129.09,129.02,128.66,127.83,126.96,125.51,120.02$, $113.23,110.12,55.11,55.04,47.04,42.52,37.13$

HRMS (DART): $m / z[\mathrm{M}+\mathrm{H}]^{+}$calcd for $\mathrm{C}_{23} \mathrm{H}_{25} \mathrm{O}_{2}: 333.18545$; found: 333.18666.

\section{1-Methoxy-3-[2-(4-methoxyphenyl)-3-phenylpropyl]benzene (3cf)}

Condition B; scale: $0.6 \mathrm{mmol}$; catalyst loading: $5 \mathrm{~mol} \%$; temperature: $0{ }^{\circ} \mathrm{C}$; time: $18 \mathrm{~h}$; colorless oil; yield: $194.0 \mathrm{mg}(97 \%) ; \alpha: \beta=1: 10 ; R_{f}=$ 0.1 (hexane $/ \mathrm{CH}_{2} \mathrm{Cl}_{2} 2: 1$ ).

IR (neat): 599, 696, 774, 826, 908, 1029, 1078, 1029, 1243, 1395, $1452,1510,1582,1596 \mathrm{~cm}^{-1}$.

${ }^{1} \mathrm{H} \mathrm{NMR}\left(\mathrm{CDCl}_{3}, 500 \mathrm{MHz}\right): \delta=7.20-7.16(2 \mathrm{H}, \mathrm{m}), 7.11-7.09(2 \mathrm{H}, \mathrm{m})$, 6.99-6.95 $(4 \mathrm{H}, \mathrm{m}), 6.73(2 \mathrm{H}, \mathrm{d}, J=7.37 \mathrm{~Hz}), 6.66(1 \mathrm{H}, \mathrm{d}, J=7.94 \mathrm{~Hz})$, $6.60(1 \mathrm{H}, \mathrm{d}, J=7.37 \mathrm{~Hz}), 6.52(1 \mathrm{H}, \mathrm{s}), 3.72(3 \mathrm{H}, \mathrm{s}), 3.68(3 \mathrm{H}, \mathrm{s}), 3.09-$ $3.07(1 \mathrm{H}, \mathrm{m}), 2.94-2.92(2 \mathrm{H}, \mathrm{m}), 2.87-2.82(2 \mathrm{H}, \mathrm{m})$.

${ }^{13} \mathrm{C}$ NMR $\left(\mathrm{CDCl}_{3}, 125 \mathrm{MHz}\right): \delta=159.24,157.77,142.15,140.49$, $136.22,129.10,128.92,128.68,127.99,125.72,121.54,114.75$, $113.42,111.13,55.07,54.97,48.79,42.62,42.60$ 
HRMS (DART): $m / z[\mathrm{M}+\mathrm{H}]^{+}$calcd for $\mathrm{C}_{23} \mathrm{H}_{25} \mathrm{O}_{2}: 333.18545$; found: 333.18535.

\section{[2-(2-Methoxyphenyl)propane-1,3-diyl]dibenzene (3ag)}

Condition A; scale: $0.6 \mathrm{mmol}$; catalyst loading: $5 \mathrm{~mol} \%$; temperature: $0{ }^{\circ} \mathrm{C}$; time: $24 \mathrm{~h}$; colorless oil; yield: $174.9 \mathrm{mg}(96 \%$, mixture of both regioisomers); $\alpha: \beta=2.2: 1 ; R_{f}=0.3$ (hexane $/ \mathrm{CH}_{2} \mathrm{Cl}_{2} 2: 1$ ).

IR (neat): 508, 601, 695, 748, 1029, 1052, 1109, 1241, 1288, 1452 , $1492,1585,1600 \mathrm{~cm}^{-1}$.

${ }^{1} \mathrm{H} \mathrm{NMR}\left(\mathrm{CDCl}_{3}, 500 \mathrm{MHz}\right): \delta=7.14-6.69(14 \mathrm{H}, \mathrm{m}), 3.62(3 \mathrm{H}, \mathrm{s}), 3.23-$ $3.22(1 \mathrm{H}, \mathrm{m}), 2.95-2.88(4 \mathrm{H}, \mathrm{m})$.

${ }^{13} \mathrm{C}$ NMR $\left(\mathrm{CDCl}_{3}, 500 \mathrm{MHz}\right): \delta$ (detectable peaks) $=157.55,140.90$, 140.82 , 130.71, 129.11, 129.09, 128.95, 127.89, 127.86, 127.03, $126.87,125.86,125.57,120.32,120.03,110.66,110.15,55.34,55.14$, $47.93,42.31,40.72,37.01$.

HRMS (DART): $m / z[\mathrm{M}+\mathrm{H}]^{+}$calcd for $\mathrm{C}_{22} \mathrm{H}_{23} \mathrm{O}$ : 303.17489; found: 303.17493.

\section{1-(2,3-Diphenylpropyl)naphthalene (3ah)}

Condition A; scale: $0.4 \mathrm{mmol}$; catalyst loading: $10 \mathrm{~mol} \%$; temperature: $0{ }^{\circ} \mathrm{C}$; time: $48 \mathrm{~h}$; colorless oil; yield: $111.4 \mathrm{mg}$ (86\%); $\alpha: \beta=$ $>20: 1 ; R_{f}=0.1$ (hexane $/ \mathrm{CH}_{2} \mathrm{Cl}_{2} 9: 1$ ).

IR (neat): 432, 525, 562, 598, 695, 756, 776, 1029, 1072, 1395, 1452, $1493,1509,1598 \mathrm{~cm}^{-1}$.

${ }^{1} \mathrm{H}$ NMR $\left(\mathrm{CDCl}_{3}, 500 \mathrm{MHz}\right): \delta=7.81(1 \mathrm{H}, \mathrm{d}, J=7.94 \mathrm{~Hz}), 7.70(1 \mathrm{H}, \mathrm{d}$, $J=8.50 \mathrm{~Hz}), 7.64(1 \mathrm{H}, \mathrm{d}, J=7.94 \mathrm{~Hz}), 7.45-7.37(2 \mathrm{H}, \mathrm{m}), 7.24-7.12(7$ $\mathrm{H}, \mathrm{m}), 7.05-7.03(4 \mathrm{H}, \mathrm{m}), 6.99(1 \mathrm{H}, \mathrm{d}, J=6.24 \mathrm{~Hz}), 3.49(1 \mathrm{H}, \mathrm{dd}, J=$ 11.90, 3.97 Hz), 3.26-3.23 (2 H, m), 3.04-3.03 (2 H, m).

${ }^{13} \mathrm{C}$ NMR $\left(\mathrm{CDCl}_{3}, 125 \mathrm{MHz}\right): \delta=144.67,140.49,136.36,133.83$, $131.90,129.26,128.74,128.13,128.09,127.73,127.33,126.66$, $126.15,125.91,125.65,125.23,125.13,123.74,48.97,42.74,39.66$.

HRMS (DART): $m / z[\mathrm{M}+\mathrm{H}]^{+}$calcd for $\mathrm{C}_{25} \mathrm{H}_{23}$ : 323.17998; found: 323.18024.

\section{(2-Propylpropane-1,3-diyl)dibenzene (3ai)}

Condition A; scale: $0.3 \mathrm{mmol}$; catalyst loading: $20 \mathrm{~mol} \%$; KOt-Bu and LiTMP were used instead of $\mathrm{KCH}_{2} \mathrm{TMS}$; temperature: $40{ }^{\circ} \mathrm{C}$; time: 18 h; colorless oil; yield: $52.8 \mathrm{mg}$ (72\%); $\alpha: \beta=1:>20 ; R_{f}=0.3$ (hexane).

IR (neat): 3061, 3027, 2956, 2925, 2868, 1601, 1495, 1452, 1376, 1031 $\mathrm{cm}^{-1}$.

${ }^{1} \mathrm{H} \mathrm{NMR}\left(\mathrm{CDCl}_{3}, 500 \mathrm{MHz}\right): \delta=7.27-7.25(4 \mathrm{H}, \mathrm{m}), 7.18-7.16(2 \mathrm{H}, \mathrm{m})$, 7.13-7.12 (4 H, m), $2.54(4 \mathrm{H}, \mathrm{d}, J=6.24 \mathrm{~Hz}), 2.01-1.93(1 \mathrm{H}, \mathrm{m}), 1.38-$ $1.34(2 \mathrm{H}, \mathrm{m}), 1.23-1.22(2 \mathrm{H}, \mathrm{m}), 0.83(3 \mathrm{H}, \mathrm{t}, J=7.37 \mathrm{~Hz})$.

${ }^{13} \mathrm{C} \mathrm{NMR}\left(\mathrm{CDCl}_{3}, 125 \mathrm{MHz}\right): \delta=141.39,129.18,128.12,125.64,41.65$, 40.16, 35.06, 19.68, 14.27 .

HRMS (Dart): $m / z$ [M $\left.+\mathrm{NH}_{4}\right]^{+}$calcd for $\mathrm{C}_{18} \mathrm{H}_{26} \mathrm{~N}$ : 256.20598; found: 256.20853.

\section{(2-Isopropylpropane-1,3-diyl)dibenzene (3aj)}

Condition A; scale: $0.3 \mathrm{mmol}$; catalyst loading: $20 \mathrm{~mol} \%$; KOt-Bu and LiTMP were used instead of $\mathrm{KCH}_{2} \mathrm{TMS}$; temperature: $40{ }^{\circ} \mathrm{C}$; time: 18 h; colorless oil; yield: $23.2 \mathrm{mg}$ (34\%); $\alpha: \beta=1:>20 ; R_{f}=0.3$ (hexane).

IR (neat): 3061, 3026, 2956, 2930, 2872, 1602, 1494, 1456, $1365 \mathrm{~cm}^{-1}$. ${ }^{1} \mathrm{H} \mathrm{NMR}\left(\mathrm{CDCl}_{3}, 600 \mathrm{MHz}\right): \delta=7.26-7.24(4 \mathrm{H}, \mathrm{m}), 7.16-7.15(2 \mathrm{H}, \mathrm{m})$, 7.11-7.10 (4 H, m), 2.60 (2 H, dd, $J=13.74,6.90 \mathrm{~Hz}), 2.43(2 \mathrm{H}, \mathrm{dd}, J=$ $13.74,7.56 \mathrm{~Hz}), 1.91-1.86(1 \mathrm{H}, \mathrm{m}), 1.72-1.67(1 \mathrm{H}, \mathrm{m}), 0.92(6 \mathrm{H}, \mathrm{d}, J=$ $7.56 \mathrm{~Hz})$.
${ }^{13} \mathrm{C} \mathrm{NMR}\left(\mathrm{CDCl}_{3}, 150 \mathrm{MHz}\right): \delta=141.88,129.07,128.16,125.58,48.26$, $36.24,27.49,18.65$.

HRMS (Dart): $m / z$ [M $\left.+\mathrm{NH}_{4}\right]^{+}$calcd for $\mathrm{C}_{18} \mathrm{H}_{26} \mathrm{~N}: 256.20598$; found: 256.20344 .

\section{Triphenyl(3-phenylpropyl)silane (5aa)}

Condition A; scale: $0.3 \mathrm{mmol}$; catalyst loading: $10 \mathrm{~mol} \%$; temperature: $0{ }^{\circ} \mathrm{C}$; time: $24 \mathrm{~h}$; colorless oil; yield: $88.8 \mathrm{mg}(78 \%) ; R_{f}=0.5$ (hexane $/ \mathrm{CH}_{2} \mathrm{Cl}_{2} 4: 1$ ).

IR (neat): 512, 576, 696, 728, 772, 858, 906, 1029, 1028, 1108, 1395, $1426,1452,1495,1509 \mathrm{~cm}^{-1}$.

${ }^{1} \mathrm{H} \mathrm{NMR}\left(\mathrm{CDCl}_{3}, 500 \mathrm{MHz}\right): \delta=7.65(6 \mathrm{H}, \mathrm{d}, J=6.80 \mathrm{~Hz}), 7.55-7.51(9$ $\mathrm{H}, \mathrm{m}), 7.42-7.41(2 \mathrm{H}, \mathrm{m}), 7.33(1 \mathrm{H}, \mathrm{t}, J=7.37 \mathrm{~Hz}), 7.28(2 \mathrm{H}, \mathrm{d}, J=7.37$ $\mathrm{Hz}), 2.83(2 \mathrm{H}, \mathrm{t}, J=7.37 \mathrm{~Hz}), 2.02-1.95(2 \mathrm{H}, \mathrm{m}), 1.59-1.56(2 \mathrm{H}, \mathrm{m})$.

${ }^{13} \mathrm{C}$ NMR $\left(\mathrm{CDCl}_{3}, 125 \mathrm{MHz}\right): \delta=142.13,135.60,135.10,129.36$, $128.56,128.21,127.83,125.69,39.71,25.76,12.81$.

HRMS (DART): $m / z$ [M $\left.+\mathrm{NH}_{4}\right]^{+}$calcd for $\mathrm{C}_{27} \mathrm{H}_{30} \mathrm{NSi}$ : 396.21475; found: 396.21406.

\section{Dimethyl(phenyl)(3-phenylpropyl)silane (5ab)}

Condition A; scale: $0.3 \mathrm{mmol}$; catalyst loading: $10 \mathrm{~mol} \%$; temperature: $0{ }^{\circ} \mathrm{C}$; time: $24 \mathrm{~h}$; colorless oil; yield: $66.6 \mathrm{mg}(87 \%) ; R_{f}=0.4$ (hexane).

${ }^{1} \mathrm{H} \mathrm{NMR}\left(\mathrm{CDCl}_{3}, 500 \mathrm{MHz}\right): \delta=7.51-7.49(2 \mathrm{H}, \mathrm{m}), 7.35-7.35(3 \mathrm{H}, \mathrm{m})$, 7.27-7.26 (2 H, m), 7.19-7.15 (3 H, m), $2.62(2 \mathrm{H}, \mathrm{t}, J=7.65 \mathrm{~Hz}), 1.67-$ $1.63(2 \mathrm{H}, \mathrm{m}), 0.82-0.79(2 \mathrm{H}, \mathrm{m}), 0.26(6 \mathrm{H}, \mathrm{s})$.

${ }^{13} \mathrm{C}$ NMR $\left(\mathrm{CDCl}_{3}, 125 \mathrm{MHz}\right): \delta=142.52,139.37,133.54,128.79$, $128.48,128.19,127.70,125.61,39.79,25.98,15.55,-3.08$

Data are in accordance with the literature. ${ }^{23}$

\section{[3-(3-Methoxyphenyl)propyl]dimethyl(phenyl)silane (5cb)}

Condition B; scale: $0.3 \mathrm{mmol}$; catalyst loading: $10 \mathrm{~mol} \%$; temperature: $0{ }^{\circ} \mathrm{C}$; time: $24 \mathrm{~h}$; colorless oil; yield: $72.3 \mathrm{mg}(85 \%) ; R_{f}=0.2$ (hexane $/ \mathrm{CH}_{2} \mathrm{Cl}_{2}$ 9:1).

IR (neat): 468, 695, 728, 772, 811, 826, 1045, 1112, 1151, 1248, 1259 , $1426,1455,1488,1583,1600 \mathrm{~cm}^{-1}$.

${ }^{1} \mathrm{H}$ NMR $\left(\mathrm{CDCl}_{3}, 500 \mathrm{MHz}\right): \delta=7.49-7.47(2 \mathrm{H}, \mathrm{m}), 7.34-7.33(3 \mathrm{H}, \mathrm{m})$, $7.18(1 \mathrm{H}, \mathrm{t}, J=7.94 \mathrm{~Hz}), 6.73-6.70(3 \mathrm{H}, \mathrm{m}), 3.77(3 \mathrm{H}, \mathrm{s}), 2.58(2 \mathrm{H}, \mathrm{t}$, $J=7.65 \mathrm{~Hz}), 1.66-1.60(2 \mathrm{H}, \mathrm{m}), 0.80-0.77(2 \mathrm{H}, \mathrm{m}), 0.25(6 \mathrm{H}, \mathrm{s})$.

${ }^{13} \mathrm{C} \mathrm{NMR}\left(\mathrm{CDCl}_{3}, 125 \mathrm{MHz}\right): \delta=159.50,144.18,139.34,133.54,129.13$, $128.79,127.70,120.92,114.23,110.82,55.07,39.82,25.85,15.55$, -3.08 .

HRMS (DART): $m / z[\mathrm{M}+\mathrm{H}]^{+}$calcd for $\mathrm{C}_{18} \mathrm{H}_{25} \mathrm{OSi}$ : 285.16747; found: 285.16694 .

\section{Funding Information}

This work was partially supported by ACT-C, JST, and AMED (S.K.), and JSPS KAKENHI Grant Number JP 17H06448 (Y.Y.). I.S. thanks JSPS Research Fellowships for Young Scientists and MERIT program, The University of Tokyo, for financial support.

\section{Supporting Information}

Supporting information for this article is available online at https://doi.org/10.1055/s-0037-1610378. 


\section{References}

(1) Vanjari, R.; Singh, K. N. Chem. Soc. Rev. 2015, 44, 8062.

(2) For selected examples, see: (a) Ueda, M.; Kondoh, E.; Ito, Y.; Shono, H.; Kakiuchi, M.; Ichii, Y.; Kimura, T.; Miyoshi, T.; Naito, T.; Miyata, O. Org. Biomol. Chem. 2011, 9, 2062. (b) Xie, P.; Xie, Y.; Qian, B.; Zhou, H.; Xia, C.; Huang, H. J. Am. Chem. Soc. 2012, 134, 9902. (c) Wu, Y.; Choy, P. Y.; Mao, F.; Kwong, F. Y. Chem. Commun. 2013, 49, 689. (d) Curto, J. M.; Kozlowski, M. C. J. Am. Chem. Soc. 2015, 137, 18. (e) Zhang, W.; Wang, F.; McCann, S. D.; Wang, D.; Chen, P.; Stahl, S. S.; Liu, G. Science 2016, 353, 1014. (f) Vasilopoulos, A.; Zultanski, S. L.; Stahl, S. S. J. Am. Chem. Soc. 2017, 139, 7705. (g) Zhang, W.; Chen, P.; Liu, G. J. Am. Chem. Soc. 2017, 139, 7709.

(3) Davies, H. M. L.; Jin, Q.; Ren, P.; Kovalevsk, A. Y. J. Org. Chem. 2002, 67, 4165.

(4) (a) Qrareya, H.; Ravelli, D.; Fagnoni, M.; Albini, A. Adv. Synth. Catal. 2013, 355, 2891. (b) Ishida, N.; Masuda, Y.; Ishikawa, N. Murakami M. 2017, 6, 669.

(5) Takemoto, S.; Shibata, E.; Nakajima, M.; Yumoto, Y.; Shimamoto, M.; Matsuzaka, H. J. Am. Chem. Soc. 2016, 138, 14836.

(6) Quite recently, elegant visible light-mediated organocatalytic asymmetric addition reactions of toluene were reported, see: Mazzarella, D.; Crisenza, G. E. M.; Melchiorre, P. J. Am. Chem. Soc. 2018, 140, 8439.

(7) (a) Comprehensive Organic Synthesis; Trost, B. M., Ed.; Pergamon Press: Oxford, 1991. (b) Comprehensive Organic Synthesis, 2nd ed.; Knochel, P.; Molander, G. A., Ed.; Elsevier Science: Amsterdam, 2014. (c) Kobayashi, S.; Matsubara, R. Chem. Eur. J. 2009, $15,10694$.

(8) An estimated value in DMSO, see: Bordwell, F. G.; Algrim, D.; Vanier, N. R. J. Org. Chem. 1977, 42, 1817.

(9) Schlosser, M. Pure Appl. Chem. 1988, 60, 1627.

(10) For a concept article, see: Yamashita, Y.; Kobayashi, S. Chem. Eur. J. 2018, 24, 10.

(11) (a) Yamashita, Y.; Suzuki, H.; Kobayashi, S. Org. Biomol. Chem. 2012, 10, 5750. (b) Sato, I.; Suzuki, H.; Yamashita, Y.; Kobayashi, S. Org. Chem. Front. 2016, 3, 1241. (c) Suzuki, H.; Sato, I.; Yamashita, Y.; Kobayashi, S. J. Am. Chem. Soc. 2015, 137, 4336. (d) Yamashita, Y.; Sato, I.; Suzuki, H.; Kobayashi, S. Chem. Asian J. 2015, 10, 2143. (e) Suzuki, H.; Igarashi, R.; Yamashita, Y.;
Kobayashi, S. Angew. Chem. Int. Ed. 2017, 56, 4520. (f) Yamashita, Y.; Igarashi, R.; Suzuki, H.; Kobayashi, S. Synlett 2017, 28, 1287. (g) Yamashita, Y.; Minami, K.; Kobayashi, S. Chem. Lett. 2018, 47, 690. (h) Yamashita, Y.; Igarashi, R.; Suzuki, H.; Kobayashi, S. Org. Biomol. Chem. 2018, 16, 5969.

(12) Yamashita, Y.; Suzuki, H.; Sato, I.; Hirata, T.; Kobayashi, S. Angew. Chem. Int. Ed. 2018, 57, 6896.

(13) For selected examples of Strong Brønsted base catalyzed addition reactions with styrenes, see: (a) Pines, H.; Kannan, S. V.; Simonik, J. J. Org. Chem. 1971, 36, 2311. (b) Rodriguez, A.; Bunlaksananusorn, T.; Knochel, P. Org. Lett. 2000, 2, 3285. (c) Yamashita, Y.; Igarashi, R.; Suzuki, H.; Kobayashi, S. Org. Biomol. Chem. 2018, 16, 5969. (d) Zhai, D. D.; Zhang, X. Y.; Liu, Y. F.; Zheng, L.; Guan, B. T. Angew. Chem. Int. Ed. 2018, 57, 1650. (e) Liu, Y. F.; Zhai, D. D.; Zhang, X. Y.; Guan, B. T. Angew. Chem. Int. Ed. 2018, 57, 8245.

(14) (a) Pines, H.; Wunderlich, D. J. Am. Chem. Soc. 1958, 80, 6001. (b) Shabtai, J.; Pines, H. J. Org. Chem. 1961, 26, 4225. (c) Shabtai, J.; Lewicki, E. M.; Pines, H.J. Org. Chem. 1962, 27, 2618. (d) Pines, H. Acc. Chem. Res. 1974, 7, 155.

(15) Steele, B. R.; Screttas, C. G. J. Am. Chem. Soc. 2000, 122, 2391.

(16) For preliminary results of catalytic addition reactions of toluene derivatives with $\beta$-substituted alkenes, see ref. 12.

(17) Schlosser, M.; Gorecka, J.; Castagnetti, E. Eur. J. Org. Chem. 2003, 452.

(18) Yttrium-catalyzed alkylations of p-methylanisole, see: Oyamada, J.; Hou, Z. Angew. Chem. Int. Ed. 2012, 51, 12828.

(19) Clegg, W.; Conway, B.; Graham, D. V.; Hevia, E.; Kennedy, A. R.; Mulvey, R. E.; Russo, L.; Wright, D. S. Chem. Eur. J. 2009, 15, 7074.

(20) Unkelbach, C.; O'Shea, D. F.; Strohmann, C. Angew. Chem. Int. Ed. 2014, 53, 553.

(21) Hogan, A.-M. L.; Tricotet, T.; Meek, A.; Khokhar, S. S.; O'Shea, D. F. J. Org. Chem. 2008, 73, 6041.

(22) (a) Stipanovic, B.; Pines, H. J. Chem. Soc. D 1969, 1361. (b) Pines, H.; Kannan, S. V.; Simonik, J. J. Org. Chem. 1971, 36, 2311. (c) Bunlaksananusorn, T.; Rodriguez, A. L.; Knochel, P. Chem. Commun. 2001, 745. (d) See alo ref. $11 \mathrm{~g}$ (e) See also ref. $11 \mathrm{~h}$.

(23) Zhou, R.; Goh, Y. Y.; Liu, H.; Tao, H.; Li, L.; Wu, J. Angew. Chem. Int. Ed. 2017, 56, 16621. 